Autores (p. o. de firma): E. Gimeno-García, V. Andreu \& J.L. Rubio

Título: Spatial patterns of soil temperatures during experimental fires

Revista: Geoderma

Volumen: 118 Página inicial: 17 Página final: 38 Año: 2004 


\title{
1 Spatial patterns of soil temperatures during experimental fires
}

2

3

\author{
E. Gimeno-García *, V. Andreu \& J.L. Rubio
}

Centro de Investigaciones sobre Desertificación- CIDE (CSIC, Universitat de València, Generalitat Valenciana). Camí de la Marjal s/n, 46700-Albal, Valencia, Spain

\section{Abstract}

The main objective of this paper is to assess the spatial patterns of temperature distribution at the soil surface after a shrubland fire in a typical Mediterranean environment. The study was carried out by making experimental fires at a permanent field station (La Concordia, Valencia, Spain) in a typical Mediterranean forest slope. The set up consisted of nine plots (20 m long by $4 \mathrm{~m}$ wide) with similar morphology, slope gradient, rock outcrops, soil (Rendzic Leptosol) and vegetation cover (Rhamno lycioidis-Quercetum cocciferae association). Two different fire severities were evaluated, high (F2) and moderate (F1), created by the addition of limited amounts of biomass. To measure soil temperatures, two complementary methods were used: thermocouples and thermosensitive paints. Results show that peak temperatures on the soil surface measured by the two systems (higher than $600^{\circ} \mathrm{C}$ in most cases) are quite similar and there are not statistically significant differences between them. The mean values of soil surface temperatures measured with thermosensitive paints were 240,239 and $218^{\circ} \mathrm{C}$ for $\mathrm{F} 1$ plots and 418,448 and $435^{\circ} \mathrm{C}$ for $\mathrm{F} 2$ plots. Half of the F1 plots surface showed temperature values between 170 and $235^{\circ} \mathrm{C}$, and in the $\mathrm{F} 2$ plots these values ranged between 322 and $543^{\circ} \mathrm{C}$. Geostatistics were applied to analyze and describe the

\footnotetext{
* Corresponding author. Tel.: +34-96-1220540; fax: +34-96-1270967. E-mail: eugenia.gimeno@uv.es
} 
spatial variation of soil temperatures at the soil surface. Results showed that there are two dominant spatial patterns of temperature distribution (spherical and linear). The spherical model varied approximately between 4 and $10 \mathrm{~m}$, and its pattern is related mainly to the natural biomass distribution and the time of flame persistence. In the second, the linear pattern, the temperature rises from the lower part to the upper part of the plot and seems to be controlled by the meteorology at the time of burning, mainly by the wind speed and wind direction.

The spatial patterns of soil temperatures during the studied experimental fires affect soil properties in different ways according to the fire severity. This fact could contribute to change the spatial dynamics of soil nutrients that will play an important role in the recovery of the burned vegetation.

Keywords: Experimental fire, Mediterranean, spatial patterns, soil properties, soil temperature

\section{Introduction}

One of the most important perturbations of Mediterranean forest ecosystems is fire, both by natural or anthropogenic causes. Fire produces a wide spectrum of responses in the affected ecosystems that depends on the interaction of many factors, including fire severity, fire intensity, duration of temperatures, fuel loading, degree of combustion, vegetation type, climate, slope, topography, soil characteristics, time since last fire, and area burned (Neary et al, 1999).

Fire severity is a qualitative measure of the effects of fire on site resources (Hartford and Frandsen, 1992; Ryan and Noste, 1983). As a physico-chemical process, fire produces a 
spectrum of effects that depends on the interaction of energy released, duration, fuel loading and combustion, vegetation type, climate, topography, soil and area burned (Robichaud et al., 2000). Fire intensity is an integral part of fire severity, and it refers to the rate at which a fire produces thermal energy (DeBano et al., 1998). Intensity is measured in terms of temperature and heat yield. Surface soil temperatures can be as a little as $50^{\circ} \mathrm{C}$ to as high as $1500{ }^{\circ} \mathrm{C}$. Heat yields per unit area can range from $1088.57 \mathrm{KJ} \mathrm{m}^{-2}$ to greater than $41868 \mathrm{KJ} \mathrm{m}^{-2}$, depending on the fuel type (Pyne et al., 1996). The most damaging component of fire severity to soil, and hence to ecosystem stability, is its duration (Robichaud et al., 2000).

Fire severity cannot be expressed as a single quantitative measure that relates to resource impact. Relative magnitudes of fire severity, expressed in terms of the post-fire appearance of litter and soil (Ryan and Noste, 1983), are widely used criteria for placing fire severity into broadly defined, discrete classes, ranging from low to high. However, some aspects of fire severity can be quantified. Because of fire effect on soil properties mainly depends on peak temperatures and their duration, several researchers have used mainly these two quantitative variables to evaluate the impact of fires on soil properties.

It is difficult to characterize fire severity within individual fires or between different fires owing to the intrinsic experimental difficulties, the great variability of combustion processes and soil conditions. During experimental fires, soil temperatures and their duration are best measured by means of thermocouples, which allow the continuous recording of temperatures at a given place. Nevertheless, obtaining detailed information on the spatial variability of those parameters using thermocouples is expensive because of the need of using a huge number of them. Thermosensitive paints are an alternative method for obtaining the spatial variability of soil temperatures during experimental fires. Although these devices only provided the maximum temperature reached at a given place, they have proved to be valuable in understanding the response of soils and organisms to spatial changes of temperature during 
a fire (DeBano and Conrad, 1978; Moreno and Oechel, 1992; Marion et al., 1991; Moreno and Oechel, 1994; Pérez and Moreno, 1998).

To assess the spatial variability of soil temperature values reached during a fire, mathematical descriptors -quantitative models- of that variation have been developed. Their applicability requires a different approach from that of classical statistics. It is embodied in the Regionalized Variable Theory, the practical application of which is Geostatistics (Webster and Oliver, 1990).

This paper is focused on the evaluation of the temperatures in the soil surface during shrub fires, through their measurement by means of thermosensitive paints, and to identify the spatial patterns of soil temperature distribution. The short-term interactions between fire severity and the immediate changes in some soil properties have also been studied.

\section{Materials and methods}

\subsection{Experimental site}

The study area of 'La Concordia' (latitude $39^{\circ} 45^{\prime} \mathrm{N}$ and longitude $0^{\circ} 43^{\prime} \mathrm{W}$ ) is located in the municipality of Lliria (Valencia, Spain), $50 \mathrm{~km} \mathrm{NW}$ of Valencia city, on land ceded by the Forestry Services of the Valencia Government (Generalitat Valenciana). The selected hillside, South-South East facing, is $575 \mathrm{~m}$ above the sea level and has a 30\% slope. The vegetation cover is a sclerophyllous shrub regenerated after a previous wildfire occurred in 1978. The dominant vegetation type belongs to the Rhamno lycioidis-Quercetum cocciferae association, which is typical of semi-arid Mediterranean areas. Climatically the area belongs to the dry ombroclimate of the lower mesomediterranean belt, according to Thornthwaite's 
classification (Rivas-Martínez, 1981). The average annual precipitation is around $400 \mathrm{~mm}$ with two maxima, autumn and spring, and a dry period from June to September. Mean monthly temperatures range from $13.3^{\circ} \mathrm{C}$ in January to $25.8^{\circ} \mathrm{C}$ in August. The soil is a Rendzic Leptosol (FAO-UNESCO, 1988) developed on Jurassic limestone, and shows a variable depth, always less than $40 \mathrm{~cm}$, good drainage, a sandy-loam texture and an alkaline pH (7.4). Soil physical and chemical properties are shown in Table 1.

The experimental set-up consists of nine plots, $20 \mathrm{~m}$ long by $4 \mathrm{~m}$ wide each, with similar morphology, slope gradient, rock outcrops, soil and vegetation cover. The location of each plot was made after intensive surveys of vegetation, soil and morphology patterns, based on an across-slope transect every $2 \mathrm{~m}$.

\subsection{Natural biomass quantification}

Composition and spatial distribution of the vegetation in each plot were determined by identifying the species, counting their individuals and measuring their size (height, maximum and minimum diameter in $\mathrm{cm}$ ), as well as the percentage of soil covered by plants on a $1 \mathrm{~m} \mathrm{x}$ $1 \mathrm{~m}$ grid basis. This information was used to map dry biomass and vegetation cover present in each square meter and to calculate the mean dry biomass present in the plots.

Dry biomass was estimated by using a non-destructive methodology similar to those proposed by Etiene (1989), Etiene and Legrand (1994) and Martínez-Fernández et al. (1991). Different algorithms and equations based on this methodology, which related dimensions and dry weight for the dominant species, were used to calculate the dry weight of each species, where the independent variable was the weight and the dependent variable was the volume. A known geometrical form was assigned to each species based on visual observations of their architecture (for example, a truncated and inverted cone for Rosmarinus officinalis and a 
cylinder for Ulex parviflorus). To quantify the dry weight, several individuals of the dominant species (8 individuals of Rosmarinus officinalis, 8 individuals of Ulex parviflorus, 3 individuals of Stipa tenaacissima, 2 individuals of Quercus coccifera) were selected in the surrounding area and their height and diameters measured. Afterwards, they were cut and the samples were taken to the laboratory, where biomass was weighed and placed in an oven $48 \mathrm{~h}$ at $55^{\circ} \mathrm{C}$ and, finally volumes and dry weights were linearly regressed. Under the three species that cover the highest percentage of soil surface (Ulex parviflorus, Rosmarinus officinalis and Quercus coccifera), 9 litter samples on a gird of $25 \mathrm{~cm} \times 25 \mathrm{~cm}$ were collected and the biomass was also directly measured.

\subsection{Experimental fire treatments}

Two experimental fire treatments were applied to reach different fire severities. The assignment of fire treatments to each plot was random. The first treatment (F1) consisted of the addition of biomass up to $2 \mathrm{~kg} \mathrm{~m}^{-2}$ to three plots. In the second treatment (F2) up to $4 \mathrm{~kg}$ $\mathrm{m}^{-2}$ was added to other three plots. The added biomass was obtained from the surrounding shrub vegetation and it was spread uniformly on the plots. This creates fuel continuity inside each plot by covering the areas of bare soil. The third set of three plots was used as a control.

Experimental fires were carried out under field conditions on 20 and 21 June 1995. Climatic parameters were monitored by a logging system of sensors placed close to the plots. Video records of the fire progression were taken to follow and to study the fire behaviour in each plot. Height sticks, 2-m long, were placed along both sides of the plots at 2-m interval, as reference points for photography and video for following the speed of the fire progression. Moreover, rate of spread of the fire front was measured by direct timing of the front passing these markers. 
To measure soil temperatures, two complementary methods were used: thermocouples

and thermosensitive paints. The first system allows to obtain information on the peak temperatures and to know the duration that the soil system is exposed to high temperatures, whereas the second system allows monitoring of the spatial distribution of peak temperatures on soil surface.

To obtain the continuous temperature-time curves on the soil surface as well as to measure the peak temperatures and their duration, thermocouples were used. Six thermocouples (type K Inconel 600 insulated) per plot were installed at ground level along parallel lines running downslope and separated from one another by $3 \mathrm{~m}$. From these measurements direct estimates were made of the time that temperature exceeded $100{ }^{\circ} \mathrm{C}$. This value was chosen because it seems to be at which the most significant changes on soil properties begin, starting with water evaporation.

To obtain the spatial distribution of temperatures on soil surface a set of thermosensitive paints were used (Omega Stick Crayons ${ }^{\circledR}$ ) ranging between $100^{\circ} \mathrm{C}$ and $677^{\circ} \mathrm{C}$, at increments of approximately $25^{\circ} \mathrm{C}$. They liquefy according to the temperature reached. A total of 24 paints were applied on iron rods $(250 \mathrm{~mm}$ long x $14 \mathrm{~mm}$ wide x $3 \mathrm{~mm}$ high). They were covered with another identical rod, but unpainted, which protect the paints from the possible disturbance produced by ashes and flames. The system was tied with two pieces of wire. Just before the experimental fire, one iron rod per square metre was placed (a total of 80 iron rods per plot) with the painted side in contact with soil. Immediately after the passage of fire, the iron rods were collected and read. In each burned plot, there were six points where thermocouples and thermosensitive paints were placed close together. Thus, a comparison between temperature measurements through both methods was made. 


\subsection{Soil analysis}

Immediately before the fires, 36 soil samples (four per plot) at 0-5 cm depth were taken. Litter was removed prior to sampling. The soil samples were air-dried, sieved to remove material with diameter $>2 \mathrm{~mm}$, and stored in airtight plastic boxes until analysis.

The soil parameters measured and the analytical methods used were: organic matter content by oxidation with potassium dichromate (Jackson, 1958); soil texture by pipette method (Ministerio de Agricultura, Pesca y Alimentación, 1986); soil bulk density (Blake and Hartage, 1986a), particle density (Blake and Hartage, 1986b); water retention capacity at field moisture level (Demolon, 1965); soil moisture content by the gravimetric method; aggregate stability by Hénin and Feodoroff method modified by Primo and Carrasco (1973); electric conductivity and pH (Richards, 1954); total carbonates (Douchafour, 1965); total nitrogen determined by micro-Kjeldahl automatic analyser using the Bremner method (Black et al., 1965); mineral nitrogen determined by steam distillation by micro-Kjeldahl automatic analyser using the Bremner method (Black et al., 1965); available phosphorus determined by colorimetry according to method of Olsen and Dean (Black et al., 1965); and cation exchange capacity determined according to the method of Bower et al. (1952).

Volumetric heat capacity was estimated using the equation proposed by Hillel (1980):

$$
C_{v}=f_{m} C_{m}+f_{o} C_{o}+f_{w} C_{w}
$$

where: $C_{v}$ is the volumetric heat capacity of the soil $\left(\mathrm{KJ} \mathrm{m}^{-3} \mathrm{~K}^{-1}\right), f_{m}$ represents the volume fraction of mineral soil (1.49 in the present case), $C_{m}$ is the volumetric heat capacity of the mineral fractions $\left(2.0 \mathrm{KJ} \mathrm{m}^{-3} \mathrm{~K}^{-1}\right)$, $f_{o}$ denotes the volume fraction of organic matter $(0.172$ in our case), $C_{o}$ is the volumetric heat capacity of the organic fraction $\left(2.51 \mathrm{KJ} \mathrm{m}^{-3} \mathrm{~K}^{-1}\right), f_{w}$ represents water fraction in the soil, and $C_{w}$ is the volumetric heat capacity of water $(4.18 \mathrm{KJ}$ $\left.\mathrm{m}^{-3} \mathrm{~K}^{-1}\right)$ 
$C_{v}$ was calculated for three different soil water conditions: dry soil $\left(f_{w}=0\right)$, soil water content at the time of sampling, and for soil field capacity. Calculations were made before and after fire and they take into account the first $5 \mathrm{~cm}$ of soil.

\subsection{Statistical Analysis}

Analysis of variance (ANOVA) was made to test significant differences between the two fire treatments. Statistical analysis of the temperature data was done in two stages: (1) description of their distribution using traditional statistics and with the median and interquartile range, which are less influenced by skewed distributions; (2) definition of semivariograms, in which the differences in nugget and total semivariance and range were examined for the variable temperature.

The semi-variance function $\gamma(\mathrm{h})$ is equal to half the expected squared difference between values at locations separated by a given lag and it is used to express spatial variations (Journel and Huijbergts, 1978). The semivariance calculation, semivariogram function model fitting and kriging were performed using the GS+ software (Gamma Design Inc.; Plainwell, MI). On each plot, 80 observations were taken at a regular interval $z(i)$, where $i=1,2, \ldots, n$, semi-variances were calculated using the equation:

$$
\gamma(\mathrm{h})=\frac{1}{2 \mathrm{~N}(\mathrm{~h})} \sum_{\mathrm{i}=1}^{\mathrm{N}(\mathrm{h})}\left[\mathrm{z}\left(\mathrm{x}_{\mathrm{i}}\right)-\mathrm{z}\left(\mathrm{x}_{\mathrm{i}+\mathrm{h}}\right)\right]^{2}
$$

where $\gamma(h)$ is the sample semivariance; $N(h)$ is the number of pairs of data points separated by the distance $h$, and $\mathrm{z}\left(x_{i}\right)$ and $\mathrm{z}\left(x_{i+h}\right)$ are the values of the temperature at locations separated by the vector $h$. This is known as the lag. We used a lag interval of $1 \mathrm{~m}$, which resulted in a minimum of nine samples in the smallest lag interval $(0-1 \mathrm{~m})$ and a maximum of 700 pairs in the1-2 m interval. Our analysis extends to a lag of $11.5 \mathrm{~m}, 2 / 3$ of the maximum lag interval. 
The isotropic semivariograms were fitted by weighted least-squares analysis to several

models. The linear, linear/sill, spherical, exponential and gaussian models were explored as models to fit the semivariogram functions for the soil temperature.

Punctual kriging, which is an exact interpolator (Delhomme, 1978), was used to estimate values of soil surface temperature for unsampled locations. To show the spatial distribution of soil temperatures throughout the plots, estimates were generated using the punctual kriging technique at $0.1-\mathrm{m}$ intervals. The 8 nearest neighbour values to an estimation point with a maximum radius of $19 \mathrm{~m}$ were used to obtain kriged estimation. The jack-knifing procedure was used to test adequacy of the selected semi-variance models plus kriging parameters (search radius, etc). Finally, the results of the kriging were displayed as a contour map.

\section{Results and discussion}

\subsection{Natural biomass distribution}

Inside the plots, marked differences in natural fuel distribution were observed. The mean values of plant and litter biomass obtained as well as the percentage of soil cover is reflected in Table 1. The most abundant species were Rosmarinus officinalis, Ulex parviflorus and Globularia alypum, which represented between 60\% (plot 8) and 90\% (plot 2) of the number of the individuals. Table 2 shows the distribution frequencies of the main species in La Concordia plots. In most plots, approximately the $50 \%$ of their surface showed a quantity of biomass $\leq$ to $0.5 \mathrm{~kg} \mathrm{~m}^{-2}$ (Figure 1). 
It is important to note that despite of the homogeneous addition of biomass in each fire

treatment, neither the compactness of the added vegetation nor their moisture content were equal to the standing biomass and litter present in each plot. Thus, differences in the spatial patterns of soil temperatures could be expected. Moreover, as it can be observed in Section 3.3., the distribution of bare soil and vegetation in a patchy shrub mosaic, typical of the Mediterranean semiarid vegetation cover pattern, play an important role during the fire spread by increasing variability of fire intensity and soil temperature.

\subsection{Behaviour of the experimental fires}

The meteorological conditions at the time of burning are reflected in Table 3. It can be seen that the experimental fires were carried out under similar climatic conditions, considering air temperature, relative humidity and wind speed. The fire front progressed rapidly upslope (in less than 2 min all the plots were covered by flames), and their behaviour were quite uniform in all the plots, except in plot 6 that suffers repeated changes in wind direction, but not affected the general pattern of fire spread. In all cases, the fire progression from their start to the lower middle part of the plots was faster in the centre of fire front than in their flanks. When the lower half part of the plots length were passed the fire front progressed more uniformly.

The description of fire behaviour in each plot was made analysing the video recording and through the observations make during the fire performance. Figures 2 and 3 show the schematic representation of fire progression. Note that the time data indicated in each figure comes from the visual and video estimation of flame persistence. The combustion processes of biomass have a longer duration. 


\subsection{Spatial variation of soil temperatures}

Table 4 shows the comparison between the maximum temperatures measured with thermocouples and thermosensitive paints. Results show that peak temperatures on the soil surface, measured by the two systems, are quite similar and there are not statistically significant differences. Thermocouples measurements in plot 7 failed, and they are not included in the statistical analysis. The significant differences between temperature values in the burned plots correspond to the different fire treatments (F1 and F2). The mean duration of soil temperatures greater than $100^{\circ} \mathrm{C}$ was 17.6 minutes for the $\mathrm{F} 1$ treatment, and 36.3 minutes for the F2 treatment.

From the thermosensitive paints, data of mean and median were used as the primary estimates of the central tendency, and the standard deviation, CV and interquartile range were used as estimates of variability (Table 5). Despite the skewness of the distributions, the mean and median values for soil temperature were similar, with the medians having smaller values than the means in most cases (Table 5).

Results obtained show that $50 \%$ of temperature values in F1 plots were between 170 and $235{ }^{\circ} \mathrm{C}$. These values ranged between 322 and $543{ }^{\circ} \mathrm{C}$ in the $\mathrm{F} 2$ plots. The mean values obtained of soil surface temperatures measured with the thermosensitive paints were 240, 239 and $218{ }^{\circ} \mathrm{C}$ for the three $\mathrm{F} 1$ plots, whereas for the F2 plots these values were 418,448 and 435 ${ }^{\circ} \mathrm{C}$ (Table 5). ANOVA shows that there are statistically significant differences between the two fire treatments.

If the mean values of soil temperature are taken into account, results show the more biomass the higher temperatures at soil surface. Mean temperature values for F2 plots are much greater $\left(\sim 200^{\circ} \mathrm{C}\right)$ than for F1 plots. However, analysing the increase of temperatures related to the amount of biomass present in the plots, it can be seen that there is not a linear 
relation between these variables (Figure 4). Nevertheless, in most cases, there are significant linear correlations between the increase in temperatures and the distance covered by the fire line (Figure 5), which means that as the flame front raised upslope the soil surface temperatures increased.

Fire behaviour is probabilistic and irregular rather than uniform; variable in intensity as well as in size (Pyne et al., 1996). When wind or slope acts on a fire, flames can be bent down and the fire adopts a direction in which concentrates its convective flow, then, more of the released heat can be directed onto new fuel. Rather than dissipating its heat in all directions, the heat is focused (Pyne et al., 1996). This is the pattern that occurs in our experimental circumstances.

The soil temperature showed differences in their spatial dependence, as determined by their semivariances. Semivariogram models and model parameters for the soil surface temperature are shown in Table 6. In our case, the spherical and linear are the best-fit models. There is no relationship between fire treatment and semivariogram best-fit model. Jackknifing procedures indicated that the model parameters plus kriging parameters are acceptable for all the semi-variogram models fitted to each plot. The resulting statistics from the jackknifing analysis show that, in all cases, the mean error is close to 0 (oscillate between 0.02 and 0.05 ) and the variance of the standardised residuals is close to 1 (between 0.7 and 1.03 ) (Table 6).

Spherical models were defined for soil temperatures measured on plots 1, 4 and 7. For plot 1 the best-fit model parameters indicated that the exponential model is best. This semivariogram approach its sill asymptotically. Strictly it has no range. For practical purposes their effective range is taken as the lag distances at which reach $0.95 \%$ of the sill variance (Webster and Olivier, 1990). In a few cases, where differences in $r^{2}$ were $<0.05$ between the spherical and alternative models, the spherical model was used to allow direct comparison of 
the nugget, sill and range values among soil temperature (Cambardella et al., 1994). In the case of plot 1 , the exponential model generates estimates of nugget and total semivariance that are similar to the spherical model, and the difference between the $\mathrm{r}^{2}$ from each model was only 0.017 .

The shape of the semivariogram for plot 1 (Figure 6a) suggests that some autocorrelation occurs among points $<3.8 \mathrm{~m}$ apart, with the strongest autocorrelation among points separated by $<1 \mathrm{~m}$ interval. Progressively, less correlation occurs among points $>2 \mathrm{~m}$ distant, such that at 3.8-m intervals, the variance attributable to autocorrelation becomes approximately equal to the population variance. Thus, sample points separated by $>3.8 \mathrm{~m}$ appears independents of one another.

The same trend is observed for temperature data in plots 4 and 7 (Figures 6b and 7c), although the range values increases. The range in plot 4 is $9.28 \mathrm{~m}$, which indicates that the spatial pattern vary each $9.8 \mathrm{~m}$, and the points $<9.8 \mathrm{~m}$ apart have more similar temperature values. In plot 7 , the range value is $10.3 \mathrm{~m}$. In these cases the range values provides an estimation of areas that have reached similar temperatures. These patches roughly coincide with the patchy distribution of pre-fire natural vegetation and litter.

Soil temperatures in plots 2 and 8 are described by a linear semivariogram (Table 6, Figures 7a and 6c), which suggests that, as the spatial distance between two measured points increases, the difference between them will also increases.

If the linear model has a slope close to zero, as occurs in plot 6 (Figure 7b), then the total variance is equal to the nugget variance and, in this case, the variable is described as spatially independent and completely random at the scale of the measurements. In the plot 6, this fact is reflected by the elevated value of nugget variance, which is $88 \%$ of the sill variance. It could mean that there is a source of spatial variation with a range much smaller than the smallest sampling interval $(1 \mathrm{~m})$. This random pattern is probably related to the 
repeated changes in wind direction observed during the course of fire in plot 6. Increasing the detail of sampling will reveal structure in the apparently random effect of the nugget variance (Burrough, 1983; Webster, 1985).

The nugget semivariance, expressed as a percentage of the total semivariance, enables comparison of the relative size of the nugget effect among the studied variable (Trangmar et al., 1985). To define distinct classes of spatial dependence among temperature in the plots, ratios similar to those represented by Cambardella et al. (1994) were used. If the ratio is $<25 \%$, the variable is considered strongly spatially dependent; if the ratio is between 25 and $75 \%$, the variable is considered moderately spatially dependent; and, if the ratio is $>75 \%$ the variable is considered weakly spatially dependent. Semivariograms parameters indicated a strong spatial dependence only for soil temperature in plot 8 . In plots 1, 2, 4 and 7, soil temperature was characterised by semivariograms with nugget/total semivariance ratios between 25 and 75\%, which indicates the existence of moderate spatial dependence. Soil temperature in plot 6 may exhibit spatial dependence at scales smaller than those used in this study $(1 \mathrm{~m})$.

Punctual kriging at 0.1-m intervals was used to produce an estimation of soil temperatures at unsampled locations inside the plots. The results are displayed as contour maps (Figures 8 - 12). As we choose punctual kriging, which is an exact interpolator in the sense that at the sampling point kriging returns the data, and as the semivariograms in all cases have a nugget variance, the maps show small discontinuities in the kriged surface.

Six contour levels are specified for temperature values in high fire severity plots (treatment F2), from $\mathrm{T}<150{ }^{\circ} \mathrm{C}$ up to $\mathrm{T}>600{ }^{\circ} \mathrm{C}$, with an interval of $75^{\circ} \mathrm{C}$. These three plots (plot 1, 4 and 8) showed $\mathrm{T}<300{ }^{\circ} \mathrm{C}$ in their lower area, where the fire started. Plot 1 showed a temperature distribution in concentric shape areas (Figure 8). We observed that there are two areas with the highest temperature values $\left(525^{\circ} \mathrm{C}\right)$, that coincided with the highest natural 
biomass points (without taking into account the added biomass). Plot 4 shows the highest values of soil temperature from $10 \mathrm{~m}$ to $16 \mathrm{~m}$ of their abscissa (Figure 9). In this case, the areas that reached $450{ }^{\circ} \mathrm{C}$ and $525{ }^{\circ} \mathrm{C}$ covered a higher percentage of plot surface than in plot 1. The spatial pattern of soil temperature observed in plots 1 and 4 , and those of their pre-fire natural biomass distribution were similar (Figures 8 and 9). In both of them, as we mentioned above, the spatial distribution of the natural vegetation and litter seems to control the temperature patches.

However, plot 8 shows clearly a linear pattern of temperature distribution that coincides with the pattern of fire progression (Figures 2 and 10). Temperatures lower than $300^{\circ} \mathrm{C}$ are located in the lower part of the plot and, as the same time as fire front spread, the temperature rises to values higher than $600^{\circ} \mathrm{C}$ at the upper part of the plot.

The contour maps of plots burned with $2 \mathrm{~kg} \mathrm{~m}^{-2}$ of additional biomass show temperatures ranging between $\mathrm{T}<150^{\circ} \mathrm{C}$ and $\mathrm{T}>400{ }^{\circ} \mathrm{C}$. Temperatures smaller than $250{ }^{\circ} \mathrm{C}$ are distributed over a great part of plot 2, covering two thirds of its total area (Figure 11). At the upper part of this plot, an increase of soil temperatures could be observed, reaching values higher than $350^{\circ} \mathrm{C}$. It shows the linear pattern of temperature distribution mentioned above.

The contour map of plot 7 (Figure 12) shows that most values are in the range of 150 $250^{\circ} \mathrm{C}$, and only two small areas showed temperatures greater than $300^{\circ} \mathrm{C}$. The highest values were not found at the upper part of the plot, as occurs when a linear pattern dominates, but temperatures greater than $250^{\circ} \mathrm{C}$ are found over areas where there was more natural biomass, and where the time of flame persistence was longer.

The results obtained suggest that the spatial patterns of soil temperatures during the experimental fires are influenced by the spatial distribution of the natural vegetation. The addition of the extra-biomass contributes to increase the temperatures as well as their residence time on soil surface, but its influence on soil temperature is only evident when the 
meteorological conditions varies during the course of the fire, especially wind speed and wind direction.

\subsection{Changes in soil properties induced by fire}

It is known that the distribution of vegetation in a patchy shrub mosaic, like in this Mediterranean semiarid environment, is related with the spatial and temporal heterogeneity of soil resources, mainly nutrients and water (Schlesinger et al., 1990). On La Concordia plots, as previously studied (Gimeno-García et al., 2001), the presence of shrubs had a clear influence on the dynamics of soil mineral nitrogen, available phosphorus and organic matter, generating a more favourable environment for the enhancement and maintenance of those nutrients than in adjoining bare areas, being a key factor on soil heterogeneity.

This vegetation distribution, which play an important role in the soil physical, chemical, hydrological and biological properties, also influence the spatial pattern of temperatures during fire, as has been observed in the present experiment. Soil surface temperatures affect soil properties (Díaz-Fierros et al., 1990; Giovannini et al., 1990; GimenoGarcía et al., 2000). Moreover, part of the nutrients accumulated in aboveground biomass and litter are deposited as ash, which contain different amounts of available nutrients in function of the fire severity (Marion et al., 1991; Grogan et al., 2000; Gimeno-García et al., 2000). The spatial patterns of soil temperatures during the studied experimental fires could affect soil properties in a different way, contributing to create a new spatial pattern of soil nutrients. The study of the spatial patterns of those changes is out of the scope of the present paper, but, undoubtedly, they will play an important role in the recovery of the vegetation in burned areas. 
Generally, the changes on soil properties did not show a linear relationship with the temperature increase during a fire. As Giovannini (1994) stated, these changes in soil properties really respond to the temperature according to a 'discrete step' model. The most important changes occur at different temperature thresholds: temperatures up to $220^{\circ} \mathrm{C}$, from 220 to $460^{\circ} \mathrm{C}$, from 460 to $600^{\circ} \mathrm{C}$ and beyond $600^{\circ} \mathrm{C}$.

In the La Concordia soil, there are significant changes in soil chemical properties according to the fire treatment. In plots burned with a moderate intensity (average temperature at the soil sampling pints was $222.5^{\circ} \mathrm{C}$ ), soil organic matter and total nitrogen contents increases after the fire by 809 and $7.6 \mathrm{~g} \mathrm{~m}^{-2}$, respectively, in the first 5 soil centimetres. However, in plots burned with high intensity (average temperature at the soil sampling points was $466^{\circ} \mathrm{C}$ ), there is a decrease in organic matter and total nitrogen by 94.2 and $5.8 \mathrm{~g} \mathrm{~m}^{-2}$, respectively. Other important changes in soil properties are reported in Table 7, like the increment in available phosphorous, ammonium nitrogen and the exchangeable cations $\mathrm{Na}, \mathrm{K}$ and $\mathrm{Mg}$, which are proportionally related to the fire severity. However, a decrease of nitrate nitrogen and exchangeable Ca is found in burned soil that is also related to fire severity.

The volumetric heat capacity of soil $(\mathrm{Cv})$ calculated before the fire was $0.82 \mathrm{KJ} \mathrm{m}^{-3} \mathrm{~K}^{-}$ ${ }^{1}$ for dry soil conditions, $1.24 \mathrm{KJ} \mathrm{m}^{-3} \mathrm{~K}^{-1}$ when the water content at the time of sampling is considered and $2.91 \mathrm{KJ} \mathrm{m}^{-3} \mathrm{~K}^{-1}$ for soil at field capacity. As consequence of the changes promoted by fire severity on soil organic matter content and soil bulk density, the estimated Cv shows some variation (Figure 13). Cv increases in moderate severity plots for the threesoil water content considered and this increment is related with the rise in soil organic matter content as well as soil bulk density. For high fire severity, there is a slight decrease in the $\mathrm{Cv}$ when soil is dry and when the soil water content at the time of sampling is considered, whereas it shows an increase when $\mathrm{Cv}$ is calculated for soil at field capacity. 
As a result of the modifications promoted by fire severity on soil properties, it could

be expected a soil nutrient redistribution related to the soil temperature patterns observed, which may be a major factor contributing to heterogeneity in soil nutrient availability and hence to shrub patchiness in this Mediterranean ecosystem. A more detailed study is needed to relate the spatial patterns of soil temperature at the time of burning and the changes in the spatial patterns of soil properties.

\section{Conclusions}

In the experimental fires carried out in this study, the mean values of soil temperature for each fire treatment were clearly different, but large variations from point to point in soil surface temperatures were observed. In spite of the addition of extra biomass, which contributes to the fire-front spread and continuity, the aboveground vegetation and litter biomass have marked effects in the soil temperature patterns. Moreover, wind speed and direction, and other characteristics of the biomass (both natural and added) as type, compaction and moisture content seems to play also an important role in the spatial distribution of soil temperatures.

We observed that soil surface temperature distribution at the burned plots in La Concordia has a moderate spatial dependence when its measurement was made at 1-m interval. Two dominant spatial patterns of temperature distribution in the plots were determined, the spherical model and the linear pattern. The fist one varied, in our case, approximately between 4 and $10 \mathrm{~m}$. This pattern is related mainly to the natural biomass distribution and the time of flame persistence. 
Temperatures increased linearly from the lower to the upper part of the plot, and seem

to be controlled by the meteorological conditions at the time of burning, mainly by the wind speed and wind direction. Both patterns of soil temperature distribution are independent of the fire treatment.

From the different methods used to asses the temperatures during fire, thermosensitive paints on $1 \mathrm{x} 1 \mathrm{~m}$ grids, together with the punctual use of thermocouples, have been demonstrated to be a useful tool for characterising the spatial pattern of soil temperatures in five of the six burned plots.

The two spatial patterns of soil temperature could play an important role in explaining the changes of soil properties after the fire (physical, chemical and biological), and especially in the spatial distribution of soil nutrients. Fire caused the losses of organic matter, total N, nitrate $\mathrm{N}$ and exchangeable calcium in the most severe case. On the other hand, an increase of ammonium $\mathrm{N}$, available phosphorous and $\mathrm{Na}^{+}, \mathrm{K}^{+}$and $\mathrm{Mg}^{2+}$ has been quantified, whereas the nitrate $\mathrm{N}$ content, the $\mathrm{CEC}$ and the exchangeable $\mathrm{Ca}^{2+}$ decrease after both severe and moderate fire. Consequently, these changes can affect the distribution and recovery of vegetation in this semiarid ecosystem that has been affected by fire because of plant competition for soil resources.

\section{Acknowledgements}

We thank Mr. J. A. Pascual for his assistance with the temperature distribution graphs and D. Rius and E. Barrachina for the soil analysis. We acknowledge support by the EU project 'Postfire soil and vegetation dynamics in natural and afforested areas in Southern Europe: The role of fire intensity’ (EV5U-91-0017) for funding this research. 
Black, C.A., Evans, D.D., White, J.L., Ensminger, L.E. and Clark, F.F., 1965. Methods of Soil Analysis: Part 2, Chemical and Microbiological Properties. American Society of Agronomy, Madison, WI.

Blake, G. R. and Hartage, K.H., 1986a. Bulk density. In: A. Klute (Editor), Methods of soil analysis, Part 1. American Scoiety of Agronomy, Masiosn, WI, pp. 1364-1367.

Blake, G. R. and Hartage, K.H., 1986b. Particle density. In: A. Klute (Editor), Methods of Soil Analysis, Part 1. American Scoiety of Agronomy, Masiosn, WI, pp. 378-379.

Bower, C.A., Reitemeir, R.F. and Fireman, M., 1952. Exchangeable cations analysis of saline and alkali soils. Soil Sci., 73: 251-261.

Burrough, P.A., 1983. Multiscale sources of spatial variation in soil. I. The application of fractal concepts to nested levels of soil variation. J. Soil Sci., 34: 577-597.

Cambardella, C., Moorman, T.B., Novak, J.M., Parkin, T.B. and Karlen, D.L., 1994. FieldScale Variability of Soil properties in Central Iowa Soils. Soil Sci. Soc. Am. J., 58: 15011511.

DeBano, L..F. and Conrad, C.E., 1978. The effect of fire on nutrients in a chaparral ecosystem. Ecology, 59: 489-497.

DeBano, L.F., Neary, D.G. and Ffolliot, P.F., 1998. Fire effects on ecosystems. John Wiley \& Sons, New York.

Delhomme, J.P.,1978. Kriging in the hydrosciences. Adv. Water Resour. 1: 251-266.

Demolon, A., 1965. Dinámica del suelo. Omega, Barcelona (in Spanish).

Díaz-Fierros, F., Benito, E., Vega, J.A., Castelao, A., Soto, B., Pérez, R and Taboada, T., 1990. Solute loss and soil erosion in burned soil from Galicia (NW Spain). In: J.G. 
Goldamer and M.J. Jenkins (Editors), Fire in Ecosystem Dynamics: Mediterranean and Northern Perspective. SPB Academic Publishing. The Hague, pp.103-116.

Douchafour, P.H., 1965. Precís de pedologie. Masson et Cie, Paris (in French).

Etiene, M., 1989. Non destructive methods for evaluating shrub biomass: a review. Acta Oecologica-Oecologia Applicata 10: 115-128.

Etiene, M. and Legrand, C., 1994. A non-destructive method to estimate shrubland biomass and combustibility. Proceedings $2^{\text {nd }}$ International Conference on Forest Fire Research, Vol. I, D.X. Viegas, Coimbra, Portugal, pp. 425-434.

FAO-UESCO. 1988. Soil Map of the World. Revised legend. 1: 5.000.000. FAO, Rome.

Gimeno-García, E., Andreu, V. and Rubio, J.L., 2000. Changes in organic matter, nitrogen, phosphorus and cations as a result of fire and water erosion in a Mediterranean landscape. Eur. J. Soil Sci., 51: 201-210.

Gimeno-García, E., Andreu, V. and Rubio, J.L.. 2001. Influence of Mediterranean shrub species on soil chemical properties in a typical Mediterranean environment. Comm. Soil Sci. Plant Anal., 32 (11-12): 1885-1898.

Giovannini, G., 1994. The effect of fire on soil quality. In: M. Sala and J.L. Rubio (Editors), Soil erosion and degradation as a consequence of forest fire. Geoforma Ediciones. Logroño, pp 15-27.

Giovannini, G., Lucchesi, S. and Giachetti, M., 1990. Effect of heating on some chemical parameters related to soil fertility and plant growth. Soil Sci., 149: 344-350.

Grogan, P., Bruns, T.D. and Chapin, F.S., 2000. Fire effects on ecosystem nitrogen cycling in a California bishop pine forest. Oecologia, 122: 537-544.

Harford, R.A. and Frandsen, W. H., 1992. When it's hot, it's hot-or maybe it's not (surface flaming may not portend extensive soil heating). Int. J. Wildland Fire, 2: 139-144.

Hillel, D., 1980. Fundamentals of Soil Physics. Academic Press, Inc. San Diego, California. 
Jackson, M.L., 1958. Soil Chemical Analysis. Prentice-Hall, Englewood Cliffs, NJ.

Journel, A.G. and Huijbregts, C.J., 1978. Mining geostatistics. Academic Press, London.

Marion, G.M., Moreno, J.M. and Oechel, W.C., 1991. Fire severity, ash deposition and clipping effects on soil nutrients in Chaparral. Soil Sci. Soc. Am. J., 55: 235-240.

Martínez-Fernández, J., López Bermúdez, F., Romero Díaz, M.A., Alonso Sarriá, F., Espinosa, V. and Javaloy, A., 1991. El matorral semiárido del sureste de España. Aportación metodológica para su evaluación. Studia Oecologica VIII: 97-105.

Ministerio de Agricultura, Pesca y Alimentación, 1986. Métodos Oficiales de Análisis. Tomo III. Secretaría General Técnica, Dirección General de Política Alimentaria, M.A.P.A., Madrid. (in Spanish).

Moreno, J.M. and Oechel, W.C., 1992. Factors controlling post-fire seedling establishment in southern California chaparral. Oecologia, 90: 50-60.

Moreno, J.M. and Oechel, W.C., 1994. Fire intensity as a determinant factor of postfire plant recovery in southern California chaparral. In: J.M. Moreno and W.C. Oechel (Editors), The Role of Fire in Mediterranean-Type Ecosystems, Ecological Studies, 107. Springer-Verlag. New York, pp. 26-45.

Neary, D.G., Klopatek, C.C., DeBano, L.F. and Ffolliott, P.F., 1999. Fire effects on belowground sustainability: a review and synthesis. Forest Ecol. Management, 122: 51-71.

Pérez, B. and Moreno, J.M., 1998. Methods for quantifying fire severity in shrubland-fires. Plant Ecology, 139: 91-101.

Primo, E. and Carrasco, J.M., 1973. Química Agrícola I: Suelos y Fertilizantes. Alhambra, Madrid (in Spanish).

Pyne, S.J., Andrews, P.L. and Laven, R.D., 1996. Introduction to Wildland Fire. John Wiley \& Sons, New York. 
Richards, L.A., 1954. Diagnosis and improvement of saline and alkali soils. USDA Agriculture Handbook, No 60.

Rivas-Martínez, S, 1981. Etages bioclimatiques, secteurs chronologiques et séries de végetation de l’Espagne Méditerranée. Ecología Mediterránea, 8 (1-2): 275-288.

Robichaud, P.R., Beyers, J.L. and Neary, D.G., 2000. Evaluating the effectiveness of postfire rehabilitation treatments. Gen. Tech. Rep. RMRS-GTR-63. Fort Colins, USDA Forest Service, Rocky Mountain Research Station.

Ryan, K.C. and Noste, N.V., 1983. Evaluating prescribed fires. Proceedings Symposium and workshop on wilderness fire. Gen. Tech. Rep. INT-182. J.E. Lotan, B.M. Kilgore, W.C. Fischer and R.W. Mutch, Ogden, UT, pp.230-238.

Schlesinger, W.H., Reynolds, J.F., Cunningham, G.L., Huenneke, L.F., Jarrell, W.M., Virginia, R.A. and Whitford, W.G., 1990. Biological feedbacks in global desertification. Sci. 247: 1043-1048.

Trangmar, B.B., Yost, R.S. and Uehara, G., 1985. Application of geostatistics to spatial studies of soil properties. Advances in Agronomy, 38: 45-94.

Webster, R., 1985. Quantitative Spatial Analysis of Soil in the Field. Advances in Soil Science, 3: 1-70.

Webster, R. and Olivier, M.A., 1990. Statistical Methods in Soil Land Resource Survey. Oxford Univ. Press, New York. 


\begin{tabular}{|c|c|c|c|}
\hline & \multicolumn{3}{|c|}{ Horizons } \\
\hline & Ah1 & Ah2 & $\mathrm{Ck}$ \\
\hline Depth (cm) & $0-12$ & $12-30$ & $30-40$ \\
\hline \% Sand (2-0.05 mm) & 60.84 & - & - \\
\hline$\%$ Silt (0.05-0.002 mm) & 27.88 & - & - \\
\hline \% Clay $(<0.002 \mathrm{~mm})$ & 7.52 & - & - \\
\hline Texture & Sandy loam & - & - \\
\hline Water retention at field capacity (\%) & 30.83 & 28.54 & 29.55 \\
\hline Aggregate stability (\%) & 32.95 & 39.70 & - \\
\hline Particle density $\left(\mathrm{g} \mathrm{cm}^{-3}\right)$ & 1.87 & - & - \\
\hline Bulk density $\left(\mathrm{g} \mathrm{cm}^{-3}\right)$ & 0.74 & - & - \\
\hline Organic matter (\%) & 9.81 & 6.22 & 4.72 \\
\hline $\mathrm{pH}$ & 7.17 & 7.30 & 7.21 \\
\hline Electric conductivity (dS.m-1) & 0.71 & 0.59 & 0.99 \\
\hline Total carbonate (\%) & 43.01 & 56.72 & 69.89 \\
\hline Total Nitrogen (\%) & 0.41 & 0.29 & 0.24 \\
\hline Mineral nitrogen (mg kg ${ }^{-1}$ ) & 15.67 & 9.63 & 17.66 \\
\hline Available phosphorus (mg kg ${ }^{-1}$ ) & 3.50 & 3.30 & 3.30 \\
\hline $\mathrm{CEC}\left(\mathrm{cmol}_{\mathrm{C}} \cdot \mathrm{kg}^{-1}\right)$ & 29.46 & 29.02 & 27.28 \\
\hline
\end{tabular}

590

Some soil physical and chemical properties of La Concordia plots 


\begin{tabular}{|c|c|c|c|c|c|c|}
\hline & \multicolumn{6}{|c|}{ Plots } \\
\hline & 1 & 2 & 4 & 6 & 7 & 8 \\
\hline Biomass $\left(\mathrm{kg} \mathrm{m}^{-2}\right)$ & 0.652 & 0.702 & 0.793 & 0.827 & 0.443 & 0.586 \\
\hline Soil cover $(\%)$ & 20.10 & 21.58 & 21.58 & 23.35 & 23.01 & 21.32 \\
\hline \multicolumn{7}{|l|}{ Species (\%) } \\
\hline Rosmarinus officinalis & 48.29 & 34.63 & 40.54 & 43.29 & 31.36 & 9.09 \\
\hline Cistus clusii & 2.93 & 0.98 & 6.31 & 0.61 & 1.78 & 4.85 \\
\hline Rhamnus lycioides & 5.37 & 3.41 & 11.71 & 4.27 & 1.18 & 3.03 \\
\hline Ulex parviflorus & 28.29 & 16.10 & 18.02 & 20.73 & 7.69 & 18.18 \\
\hline Globularia alypum & 6.83 & 40.00 & 18.92 & 20.12 & 47.93 & 30.91 \\
\hline Thymus vulgaris & 1.46 & 0.49 & 2.70 & 4.27 & 7.69 & 23.64 \\
\hline Stipa tenacissima & 0.49 & 2.44 & - & 3.66 & - & 0.61 \\
\hline Erica multiflora & 1.95 & - & - & - & - & - \\
\hline Pinus halepensis & 0.49 & - & - & 0.61 & - & 0.61 \\
\hline Quercus coccifera & 3.90 & - & 0.90 & - & 2.37 & 8.48 \\
\hline Anthyllis cytisoides & - & 1.95 & 0.90 & 2.44 & - & 0.61 \\
\hline Brachypodium retusum & +++ & +++ & +++ & +++ & +++ & +++ \\
\hline
\end{tabular}

Vegetation characteristics of La Concordia: Plant community composition, mean total aboveground biomass per plot (standing plants and litter), cover percentage in each plot before the experimental fires and percentage of the dominant species

(-) Absent 
Table 3

601 Meteorological conditions during experimental fires and fire spread rate

\begin{tabular}{ccccccc}
\hline \multicolumn{1}{c}{ Date } & Burned plots & $\begin{array}{c}\text { Air temperature } \\
\left({ }^{\circ} \mathrm{C}\right)\end{array}$ & $\begin{array}{c}\text { Relative humidity } \\
(\%)\end{array}$ & $\begin{array}{c}\text { Wind rate } \\
\left(\mathrm{m} \mathrm{s}^{-1}\right)\end{array}$ & $\begin{array}{c}\text { Prevailing wind } \\
\text { Rate of fire front } \\
\left(\mathrm{m} \mathrm{s}^{-1}\right)\end{array}$ \\
\hline 20 June 1995 & 1 & 21 & 71 & 0.3 & $\mathrm{SE}$ & 0.081 \\
& 2 & 22 & 71 & 0.3 & $\mathrm{SE}$ & 0.210 \\
\hline 21 June 1995 & 4 & 20 & 85 & 0.3 & $\mathrm{SE}$ & 0.133 \\
& 6 & 24 & 79 & $0.3-1.4$ & SE and SW & 0.222 \\
& 7 & 22 & 82 & 0.3 & SE & 0.266 \\
\hline
\end{tabular}

602 
(a) Average and peak soil temperatures $\left({ }^{\circ} \mathrm{C}\right)$ measured with thermosensitive paints and 605 thermocouples at the same points $(n=6)$ in La Concordia plots and (b) results of the ANOVA test to study statistical differences between the burned plots and between the two methods for measuring temperatures

608

609

(a)

\begin{tabular}{cccccc} 
& & \multicolumn{2}{c}{ Average T } & \multicolumn{2}{c}{ Peak T } \\
\cline { 3 - 5 } Fire treatment & Plot & Paints & Thermocouples & Paints & Thermocouples \\
\hline F1 & 2 & 301.0 & 347.3 & 525 & 440 \\
(biomass $2 \mathrm{~kg} \mathrm{~m}^{-2}$ ) & 6 & 266.3 & 381.8 & 621 & 633 \\
\hline & 7 & 209.5 & $-{ }^{\text {a }}$ & 621 & - \\
F2 & 1 & 516.6 & 451.5 & 677 & 639 \\
(biomass $4 \mathrm{~kg} \mathrm{~m}^{-2}$ ) & 4 & 546.8 & 629.5 & 677 & 654 \\
\hline
\end{tabular}

610

611

612

613

\begin{tabular}{lccccc}
\hline \multicolumn{1}{c}{ Source } & $\begin{array}{l}\text { Sum of } \\
\text { squares }\end{array}$ & $d f$. & Mean squares & F ratio & Significance \\
\hline Plot & 625079.9 & 4 & 156269.9 & 10.975 & 0.000 \\
Method measurement & 30826.6 & 1 & 30826.6 & 2.165 & 0.147 \\
Plot x Method & 55261.1 & 4 & 13815.3 & 0.970 & 0.432 \\
Error & 711937.0 & 50 & 14238.7 & & \\
\hline
\end{tabular}

a Thermocouples in plot 7 failed during the experimental fire, so the data are not included

(b) 
Table 5

616 Summary statistics for temperature data $\left({ }^{\circ} \mathrm{C}\right)$ measured with the thermosensitive paints

617

\begin{tabular}{lcccccc}
\hline Fire treatment & \multicolumn{3}{c}{ F2 $\left(4 \mathrm{~kg} \mathrm{~m}^{-2}\right)$} & \multicolumn{3}{c}{$\mathrm{F} 1\left(2 \mathrm{~kg} \mathrm{~m}^{-2}\right)$} \\
\hline Plot & 1 & 4 & 8 & 2 & 6 & 7 \\
\hline $\mathrm{N}$ & 80 & 80 & 80 & 80 & 80 & 80 \\
Mean $\left({ }^{\circ} \mathrm{C}\right){ }^{\mathrm{a}}$ & $417.78 \mathrm{a}$ & $448.09 \mathrm{a}$ & $434.91 \mathrm{a}$ & $239.90 \mathrm{~b}$ & $239.46 \mathrm{~b}$ & $217.54 \mathrm{~b}$ \\
Median & 420.00 & 454.00 & 420.00 & 226.00 & 226.00 & 198.00 \\
Std. deviation ${ }^{\mathrm{b}}$ & 118.78 & 132.63 & 147.32 & 90.71 & 91.58 & 81.61 \\
CV $(\%){ }^{\mathrm{c}}$ & 28.43 & 29.597 & 33.874 & 37.81 & 38.245 & 37.516 \\
IQR ${ }^{\mathrm{d}}$ & 177.25 & 200.75 & 182.00 & 65.00 & 65.00 & 65.00 \\
Mínimum $\left({ }^{\circ} \mathrm{C}\right)$ & 226 & 170 & 170 & 101 & 149 & 76 \\
Máximum $\left({ }^{\circ} \mathrm{C}\right)$ & 677 & 677 & 677 & 525 & 621 & 621 \\
Skewness & 0.127 & -0.030 & 0.145 & 1.731 & 2.186 & 2.381 \\
Kurtosis & -0.749 & -0.717 & -0.663 & 2.824 & 5.947 & 8.239 \\
Variance & 14108 & 17589 & 21705 & 8227 & 8387 & 6661 \\
\hline
\end{tabular}

618

619

620

${ }^{a}$ Different lower case letter among F1 and F2 treatments indicates statistically significant difference at $\mathrm{P}<0.05$

b Standard deviation

${ }^{\mathrm{c}}$ Coefficient of variation

${ }^{\mathrm{d}}$ Interquartile range

625 
Table 6

Parameters of the geoestatistical analysis of soil surface temperature distribution in La Concordia experimental plots

628

\begin{tabular}{|c|c|c|c|c|c|c|c|}
\hline & Plots & 1 & 2 & 4 & 6 & 7 & 8 \\
\hline \multirow{6}{*}{ 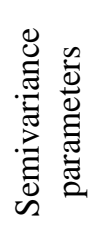 } & Lag distance maximum & 19.235 & 19.235 & 19.235 & 19.235 & 19.235 & 19.235 \\
\hline & Lag distance active & 11.541 & 11.541 & 11.541 & 11.541 & 11.541 & 11.541 \\
\hline & Step size mínimum & 1 & 1 & 1 & 1 & 1 & 1 \\
\hline & Step size active & 2 & 2 & 2 & 2 & 2 & 2 \\
\hline & $\mathrm{N}^{\mathrm{o}}$ classes lag & 5 & 5 & 5 & 5 & 5 & 5 \\
\hline & Pairs of points per class & $>250$ & $>250$ & $>250$ & $>250$ & $>250$ & $>250$ \\
\hline \multirow{6}{*}{ 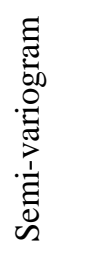 } & Best fit isotropic model & Spherical & Linear & Spherical & Linear & Spherical & Linear \\
\hline & & 0.788 & 0.708 & 0.874 & 0.199 & 0.957 & 0.959 \\
\hline & Nugget variance $\left(\mathrm{c}_{0}\right)$ & 7230 & 4718.2 & 10700 & 7808 & 5000 & 3952.6 \\
\hline & Sill $\left(c_{0}+c\right)$ & 14220 & 8366.7 & 18190 & 8893 & 8547 & 27537 \\
\hline & Range $\left(\mathrm{a}_{0}\right)$ & 3.81 & 11.541 & 9.280 & 11.541 & 10.29 & 11.541 \\
\hline & (Nugget /Sill) $^{\mathrm{a}}$ & $50.84 \mathrm{M}$ & $56.39 \mathrm{M}$ & $58.82 \mathrm{M}$ & $87.79 \mathrm{~W}$ & $58.50 \mathrm{M}$ & $14.35 \mathrm{~S}$ \\
\hline \multirow{4}{*}{ 禹 } & Type of kriging & Punctual & Punctual & Punctual & Punctual & Punctual & Punctual \\
\hline & Interval between points & 0.1 & 0.1 & 0.1 & 0.1 & 0.1 & 0.1 \\
\hline & Size radius & 19.235 & 19.235 & 19.235 & 19.235 & 19.235 & 19.235 \\
\hline & $\mathrm{N}^{\circ}$ maximum neighbours & 8 & 8 & 8 & 8 & 8 & 8 \\
\hline \multirow{2}{*}{ 它 } & Reduced error. Mean & 0.039 & 0.030 & 0.02 & 0.053 & 0.024 & 0.055 \\
\hline & Reduced error. Variance & 0.708 & 0.837 & 0.708 & 0.766 & 0.702 & 1.030 \\
\hline
\end{tabular}

${ }^{\text {a }}$ Class of spatial dependence. W: weak; M: moderate; S: strong 
Table 7

634 Changes of soil properties in La Concordia plots as consequence of fire at the soil sampling points for each fire treatment. Values followed by $(+)$ indicate an increase respect their values 636 before burning and values followed by (-) indicate a decrease respect their values before the 637 fire

638

\begin{tabular}{|c|c|c|}
\hline & \multicolumn{2}{|c|}{ Fire severity } \\
\hline & Moderate & High \\
\hline Organic matter $\left(\mathrm{g} \mathrm{m}^{-2}\right.$ ) & $809.1(+)$ & $94.2(-)$ \\
\hline Total Nitrogen $\left(\mathrm{g} \mathrm{m}^{-2}\right)$ & $7.6(+)$ & $5.8(-)$ \\
\hline Ammonium Nitrogen $\left(\mathrm{g} \mathrm{m}^{-2}\right)$ & $1.7(+)$ & $3.0(+)$ \\
\hline Nitrate Nitrogen $\left(\mathrm{g} \mathrm{m}^{-2}\right)$ & $0.4(-)$ & $0.7(-)$ \\
\hline Available Phosphorus $\left(\mathrm{g} \mathrm{m}^{-2}\right.$ ) & $1.2(+)$ & $2.0(+)$ \\
\hline $\mathrm{Na}^{+}\left(\mathrm{g} \mathrm{m}^{-2}\right)$ & $6.1(+)$ & $5.9(+)$ \\
\hline $\mathrm{K}^{+}\left(\mathrm{g} \mathrm{m}^{-2}\right)$ & $7.3(+)$ & $9.8(+)$ \\
\hline $\mathrm{Mg}^{2+}\left(\mathrm{g} \mathrm{m}^{-2}\right)$ & $1.4(+)$ & $1.4(+)$ \\
\hline $\mathrm{Ca}^{2+}\left(\mathrm{g} \mathrm{m}^{-2}\right)$ & $46.5(-)$ & $55.0(-)$ \\
\hline
\end{tabular}

639

640 

Concordia plots

Figure 2. Schematic representation of fire progression for the plots of high fire severity (F2).

Lines inside the plots indicate the fire progression at different time intervals. The numbers correspond with the time (minutes and seconds) of fire spread across the plots. Arrows indicates the main changes of wind direction

651

Figure 1. Natural biomass distribution ranges $\left(\mathrm{kg} \mathrm{m}^{-2}\right)$ and their percentages in the La

\section{1}

2

Figure 3. Schematic representation of fire progression for the plots of moderate fire severity (F1). Lines inside the plots indicate the fire progression at different time intervals. The numbers correspond with the time (minutes and seconds) of fire spread across the plots. Arrows indicates the main changes of wind direction

Figure 4. Relationship between soil temperature at the soil surface and amount of natural biomass per square metre in the burned plots

Figure 5. Soil temperature at the soil surface in each burned plot related with the distance covered by the fire line. Zero value from $\mathrm{X}$ axis represents the fire start point

Figure 6. Experimental semivariograms and fitted models for soil temperature in F2 plots. (a) Spherical model for plot 1; (b) Spherical model for plot 4; (c) Lineal model for plot 8. Symbols are the experimental semivariances $(\gamma)$ and the solid line represents the fitted model 
681

682

683

684

685

686

687

688

689

Figure 7. Isotropic semivariograms and fitted models for soil temperature in F1 plots. (a) Lineal model for plot 2; (b) Lineal model for plot 6; (c) Spherical model for plot 7. Symbols are the experimental semivariances $(\gamma)$ and the solid line represents the fitted model

Figure 8. Map of the kriged estimates for temperature at the soil surface of Plot 1 measured with thermosensitive paints (right) and spatial distribution of natural biomass amount per square metre (left)

Figure 9. Map of the kriged estimates for temperature at the soil surface of Plot 4 measured with thermosensitive paints (right) and spatial distribution of natural biomass amount per square metre (left)

Figure 10. Map of the kriged estimates for temperature at the soil surface of Plot 8 measured with thermosensitive paints of Plot 8 (right) and spatial distribution of natural biomass amount per square metre (left)

Figure 11. Map of the kriged estimates for temperature at the soil surface of Plot 2 measured with thermosensitive paints (right) and spatial distribution of natural biomass amount per square metre (left)

Figure 12. Map of the kriged estimates for temperature at the soil surface of Plot 7 measured with thermosensitive paints (right) and spatial distribution of natural biomass amount per square metre (left) 
691 dry soil; (B) soil water content at the time of sampling; (C) soil at field capacity. Calculations 692 were made before fire and after fire for the three fire treatments: High fire severity $(H)$, 693 Moderate fire severity (M); Control treatment (C) 
695

696

697

698

699

700

701

702

703

704

705

706

707

708

709

710

711

712

713

714

715

Fig. 1
P1

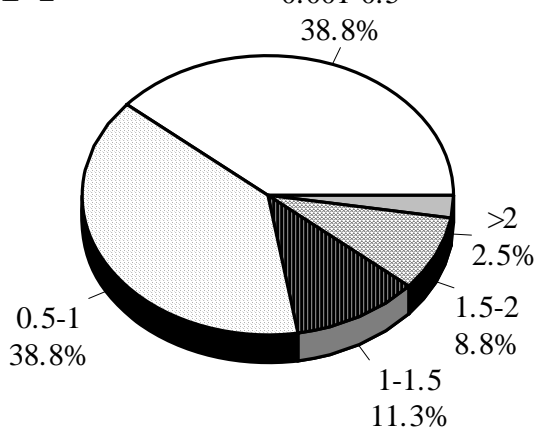

P4

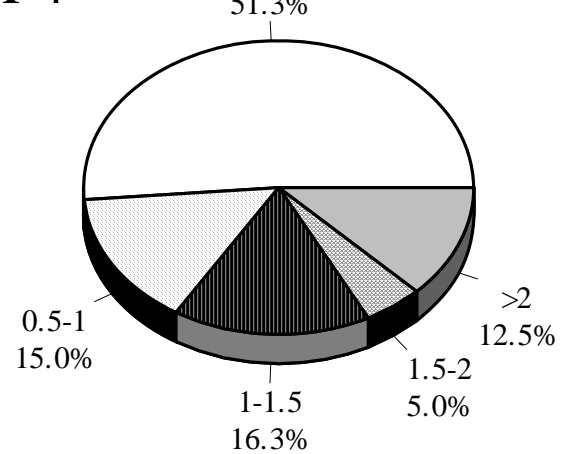

$16.3 \%$

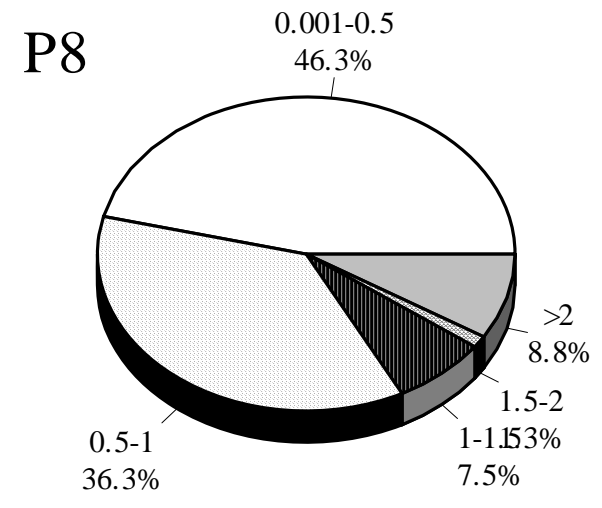

P2 0.001-0.5

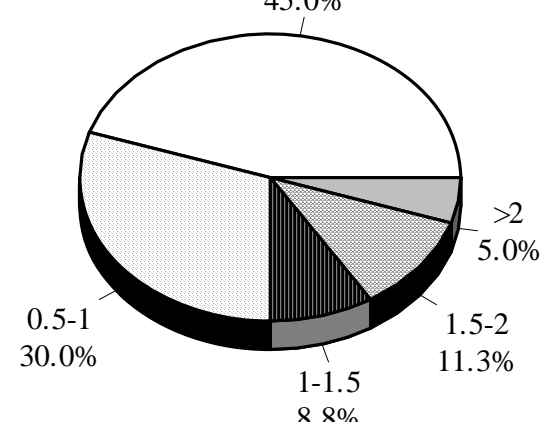

P6

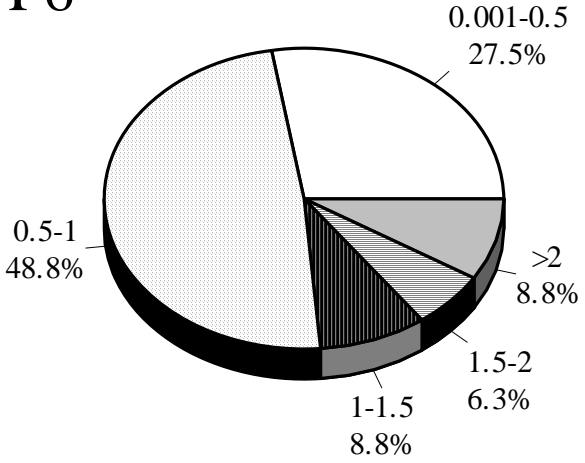

P7

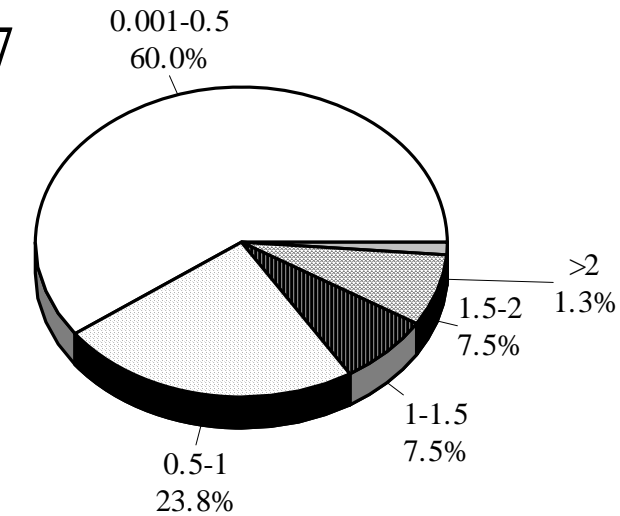

1-1.5

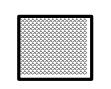

1.5-2

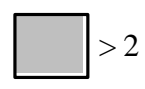




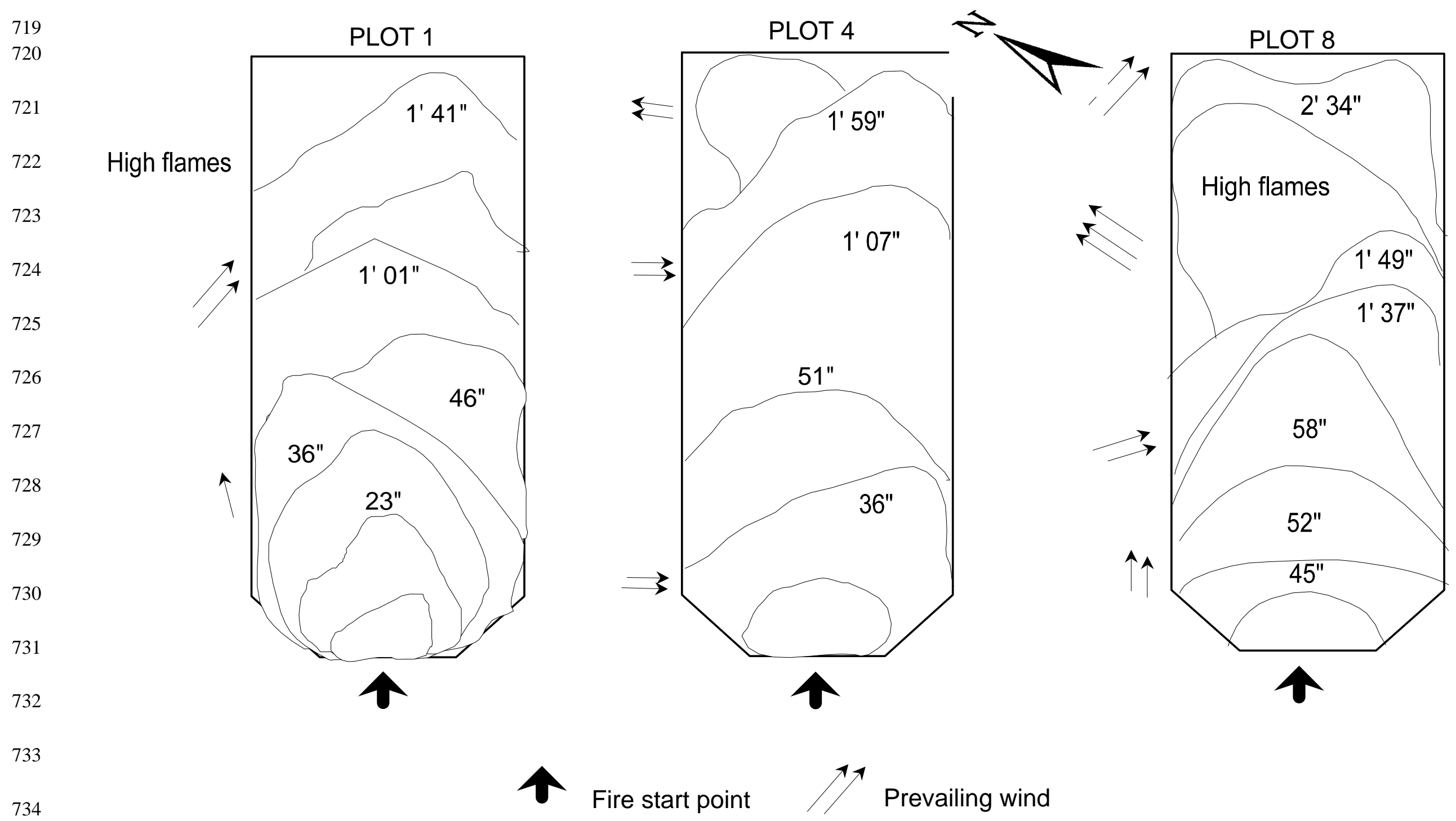

$735 \quad$ Fig. 2 


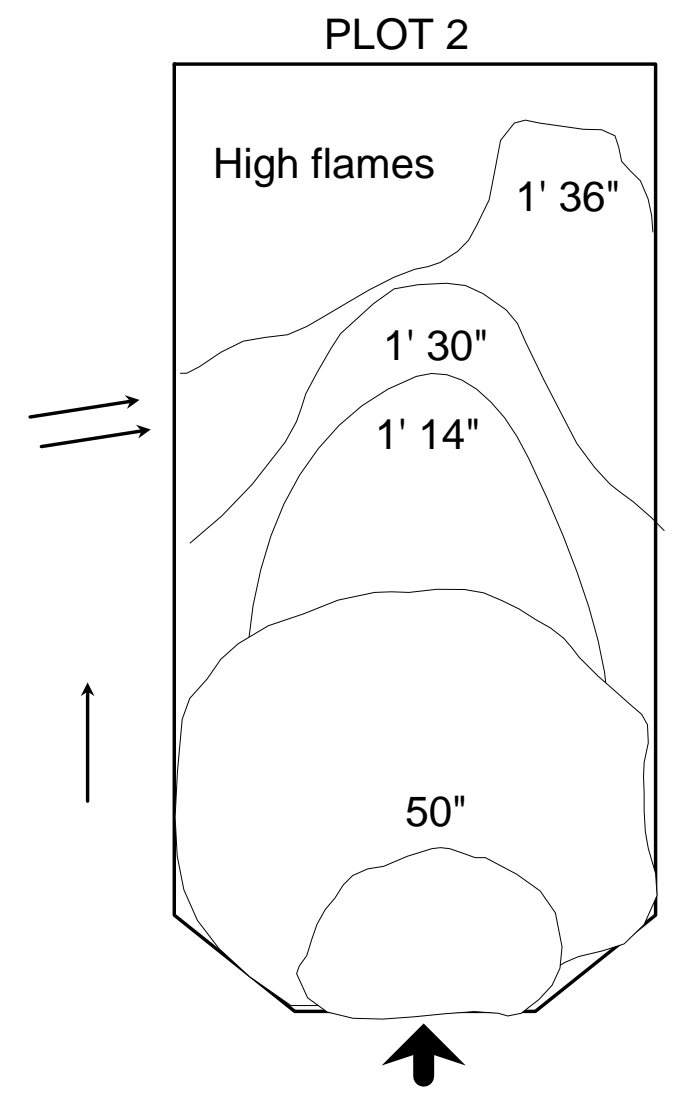

Fig. 3
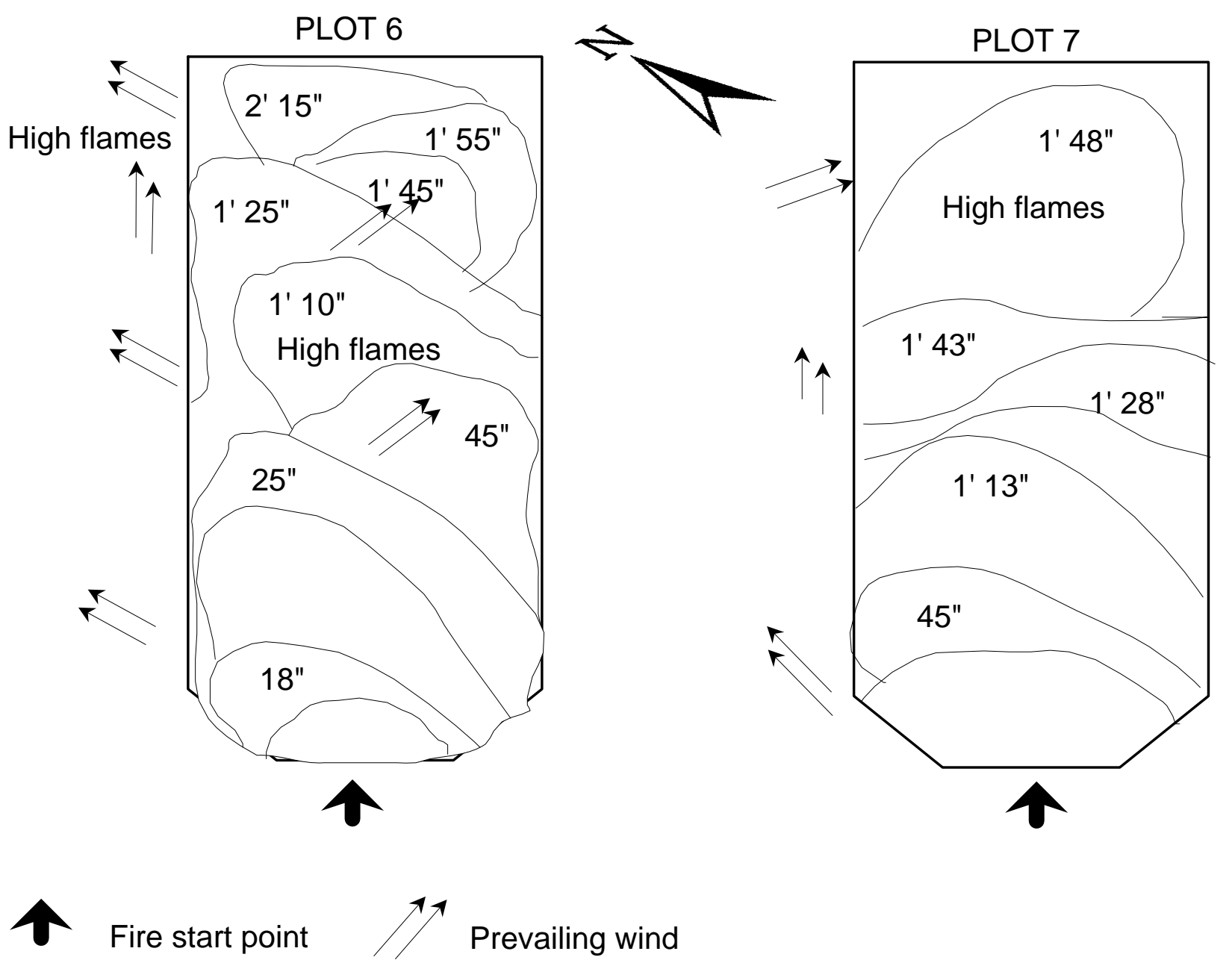
PLOT 1

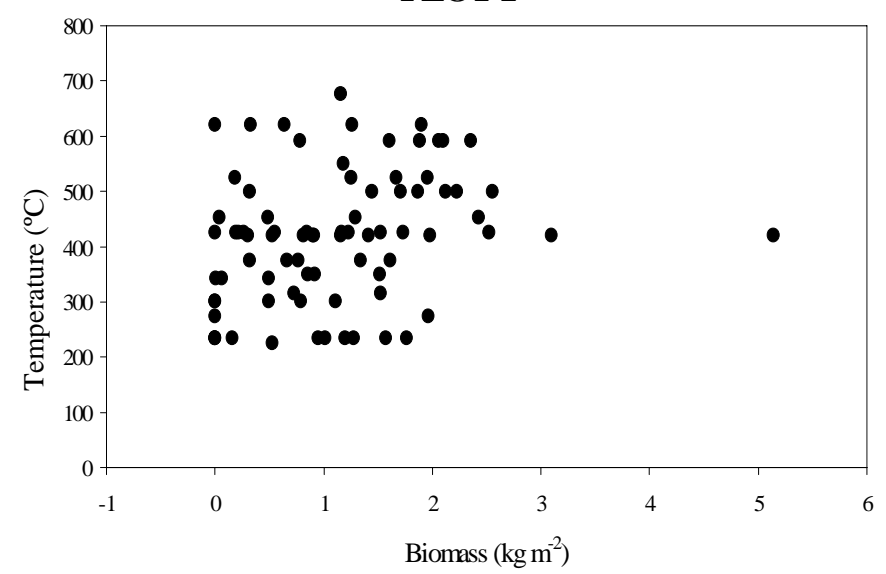

PLOT 4
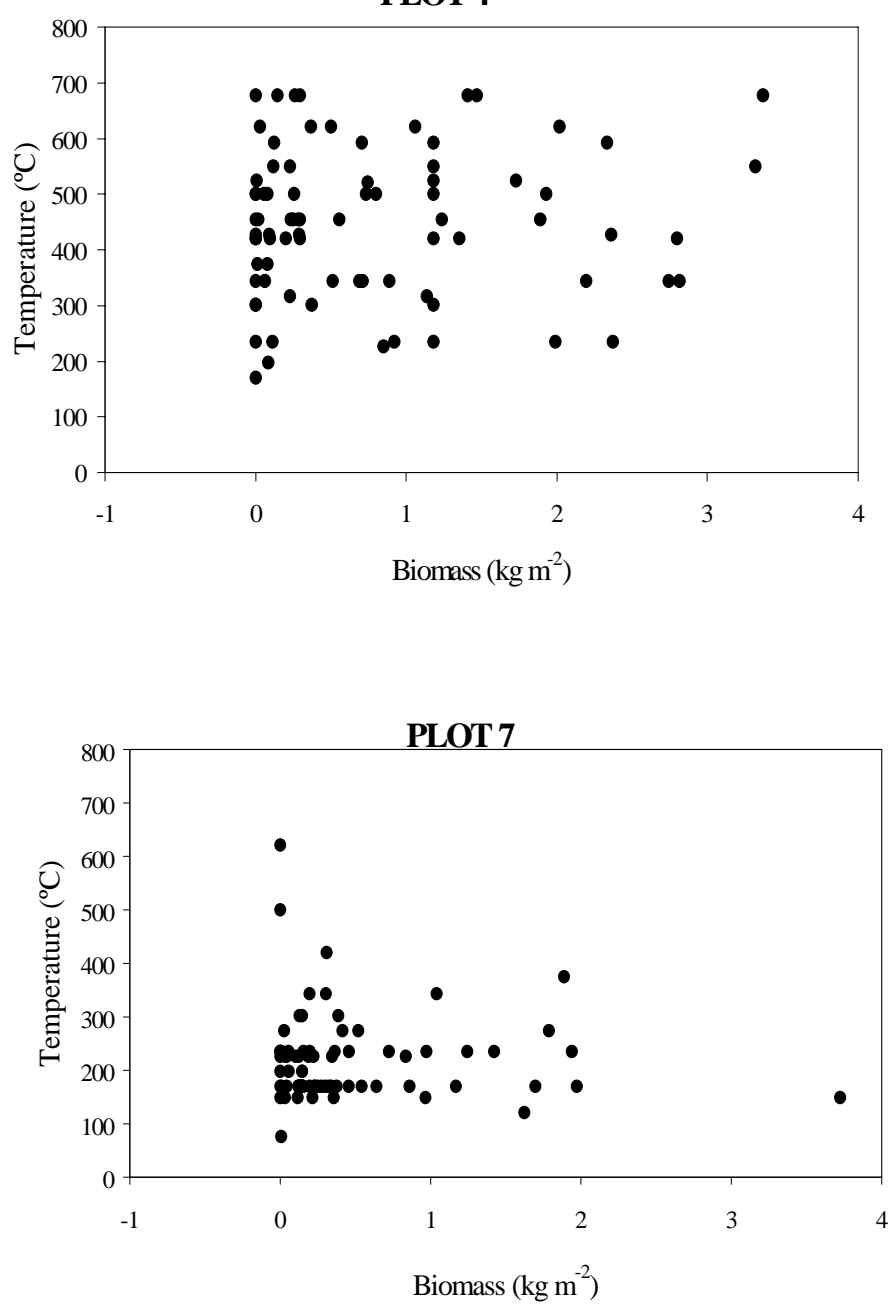

753 Fig. 4
PLOT 2

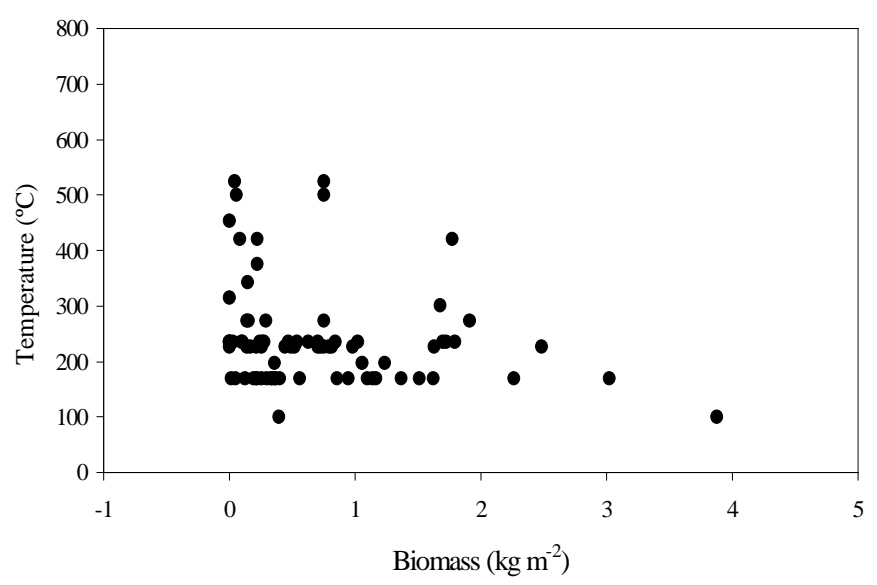

PLOT 6
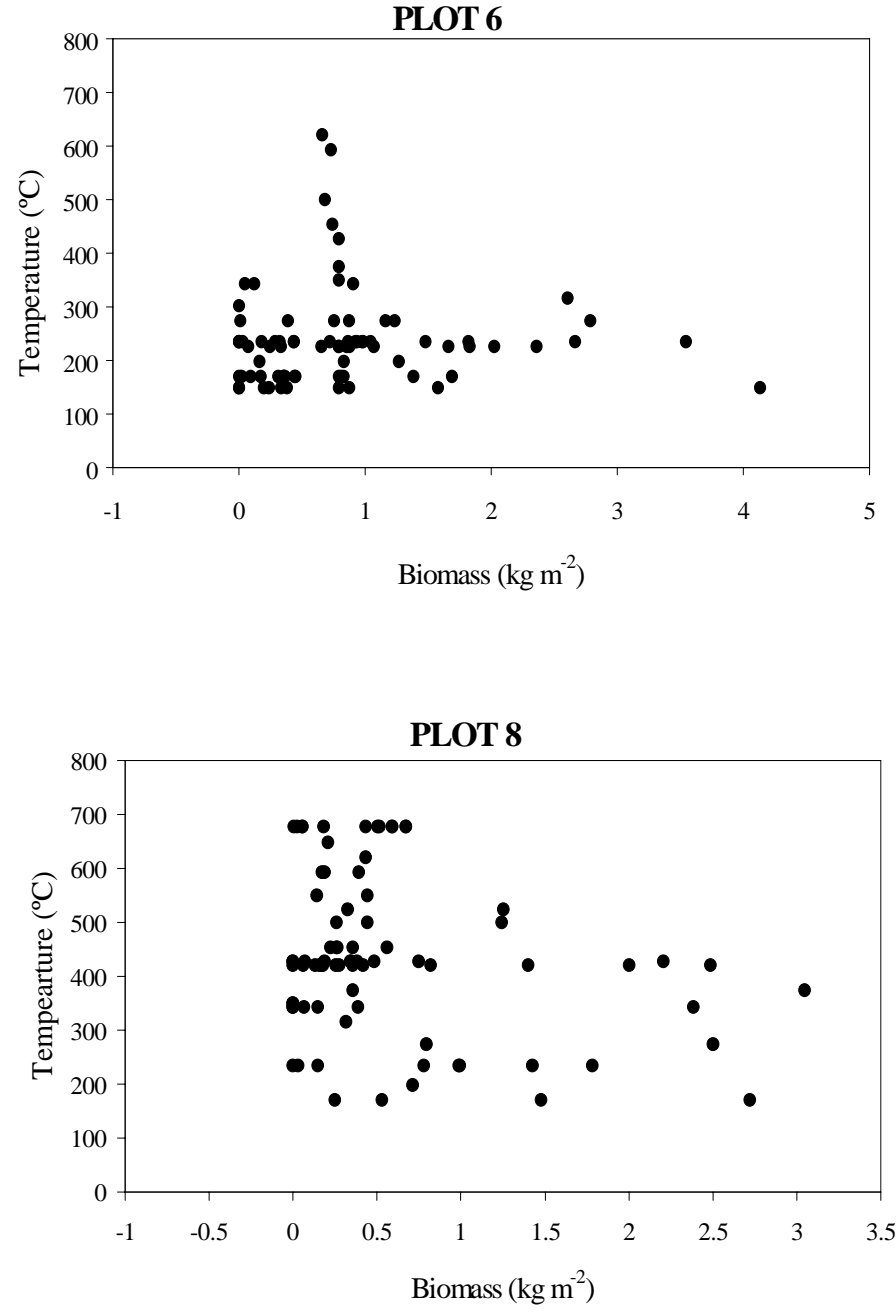

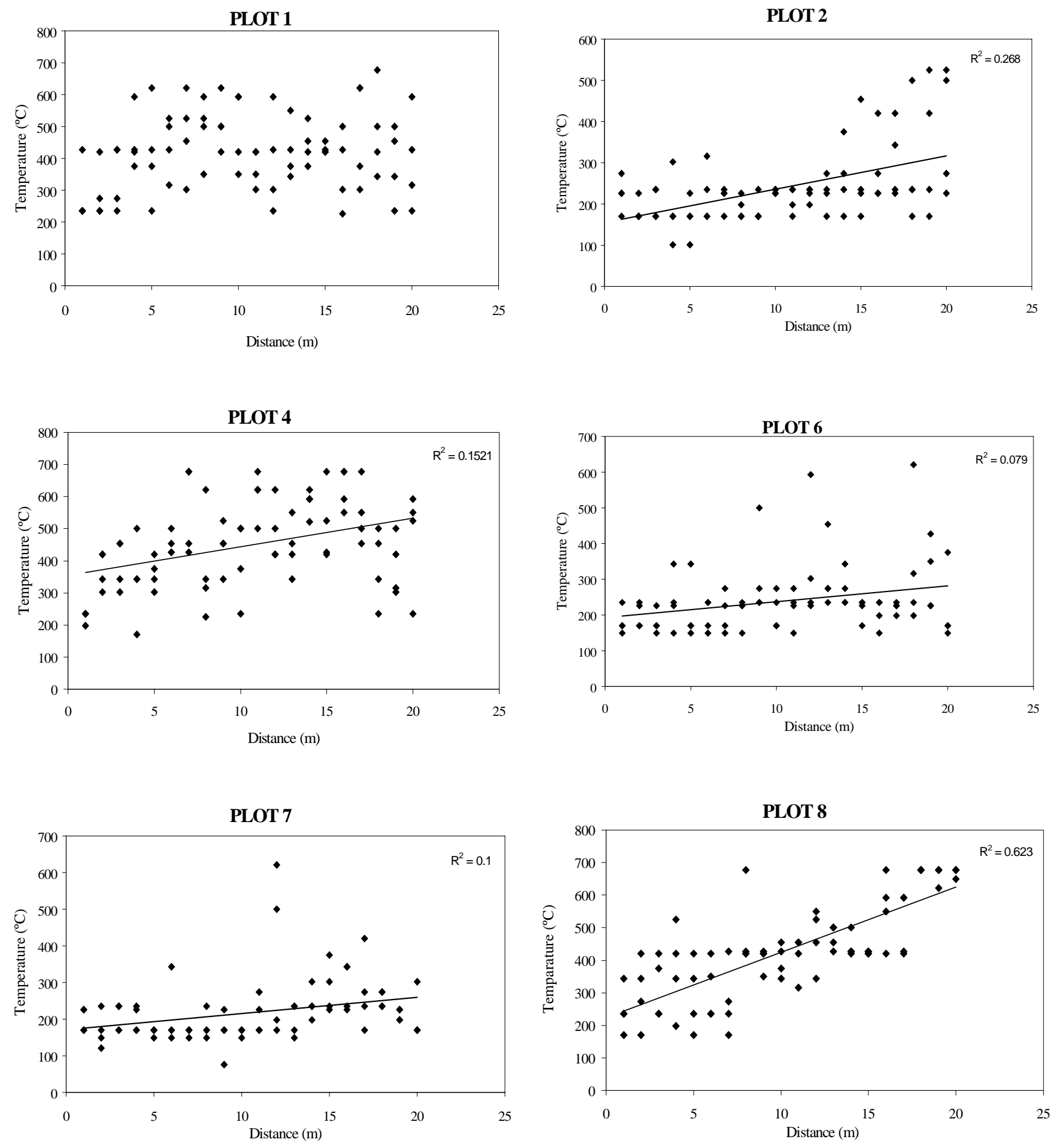

755

756

Fig. 5

757 
(a) Plot 1

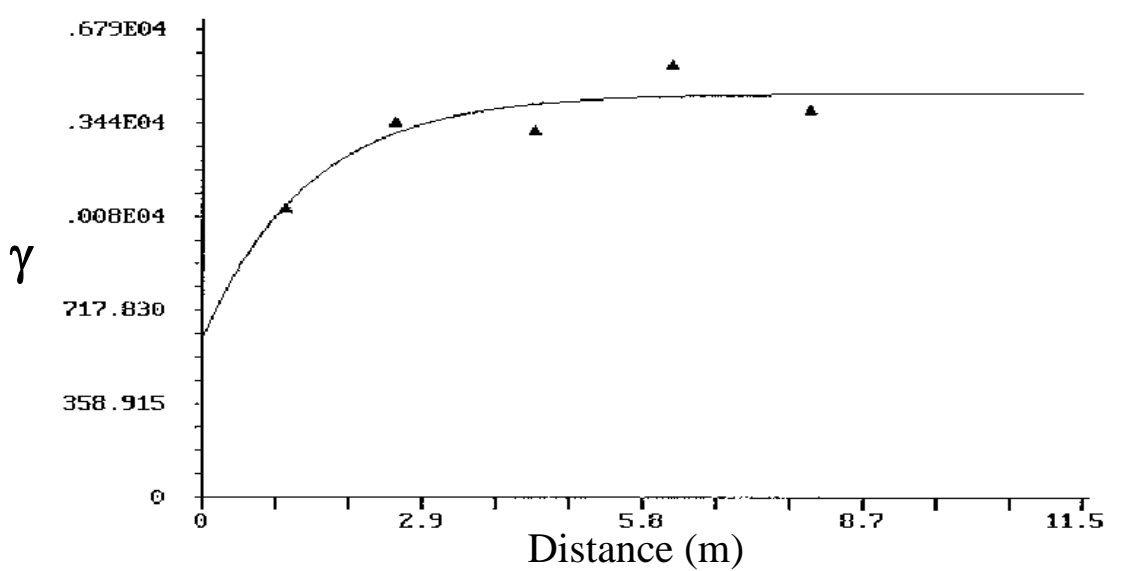

(b) Plot 4

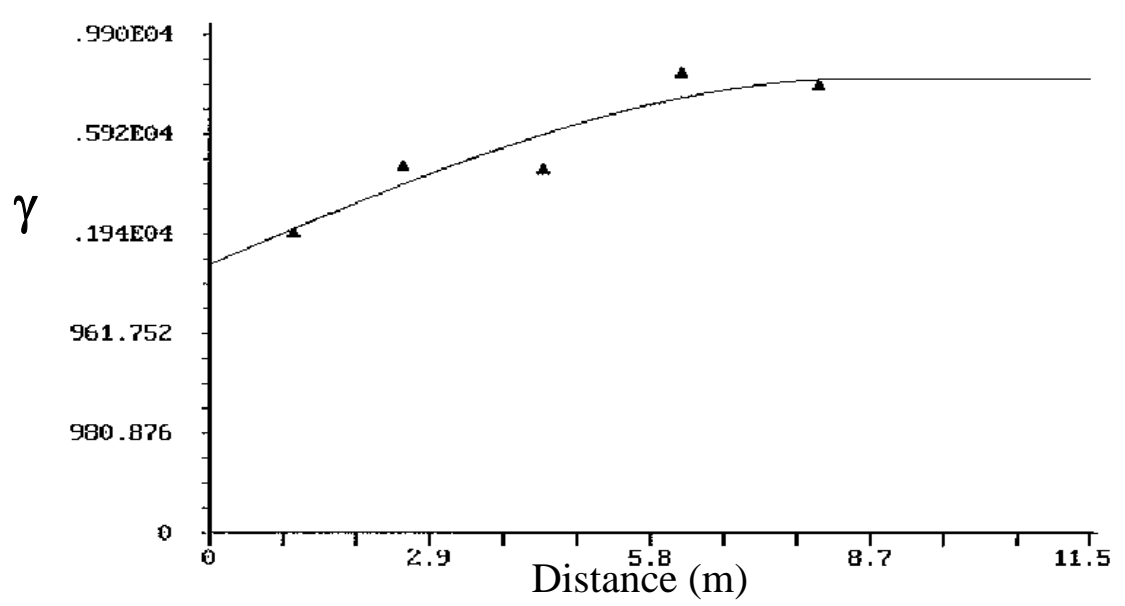

(c) Plot 8

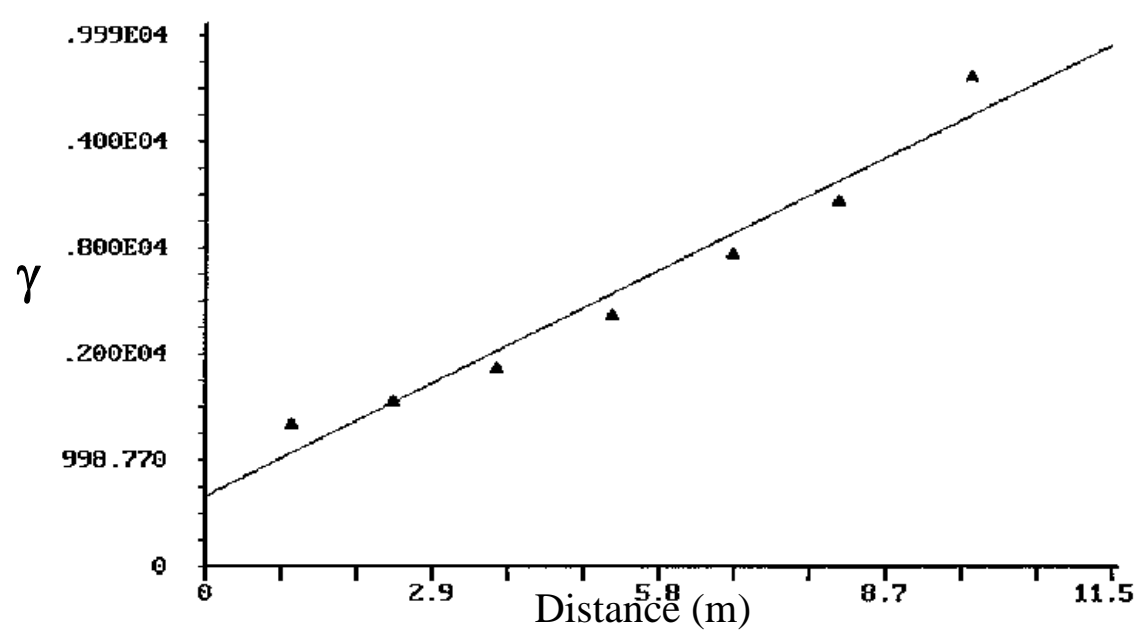

Fig. 6 
(a) Plot 2

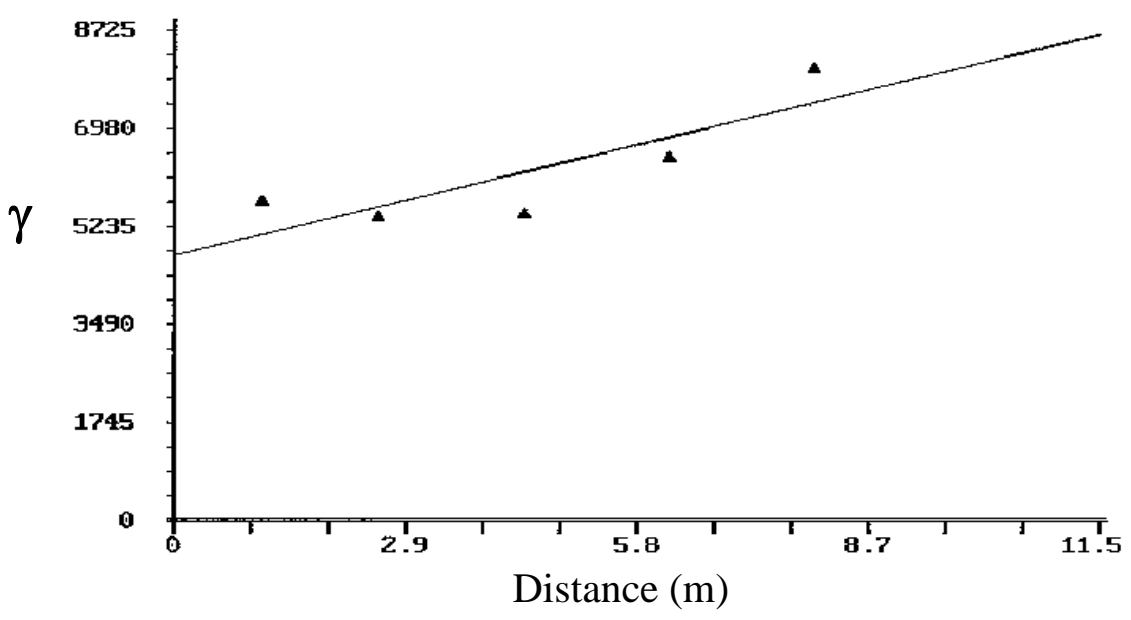

(b) Plot 6

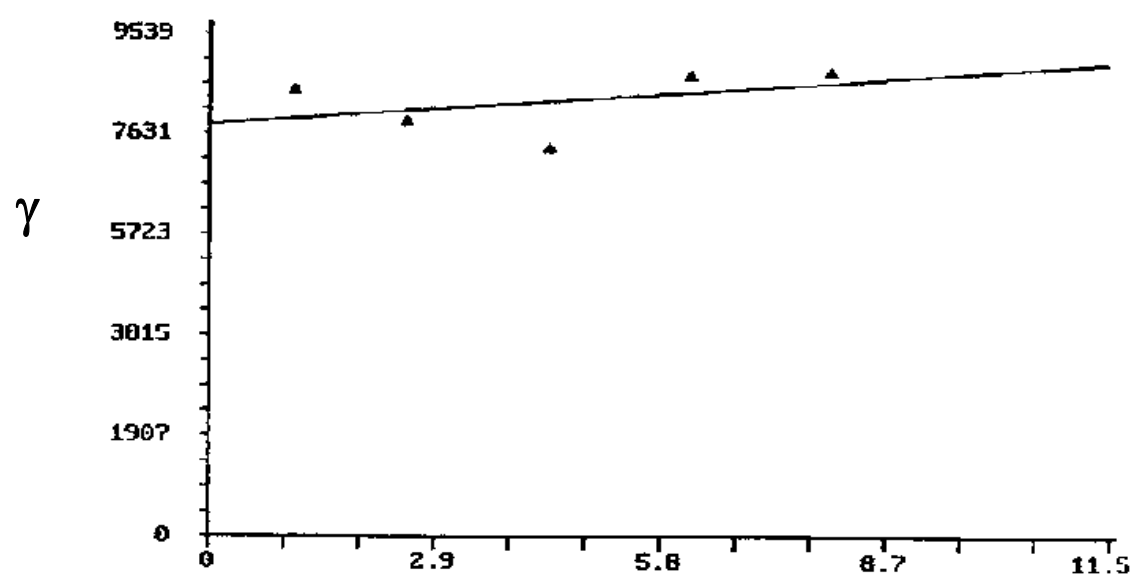

Distance (m)

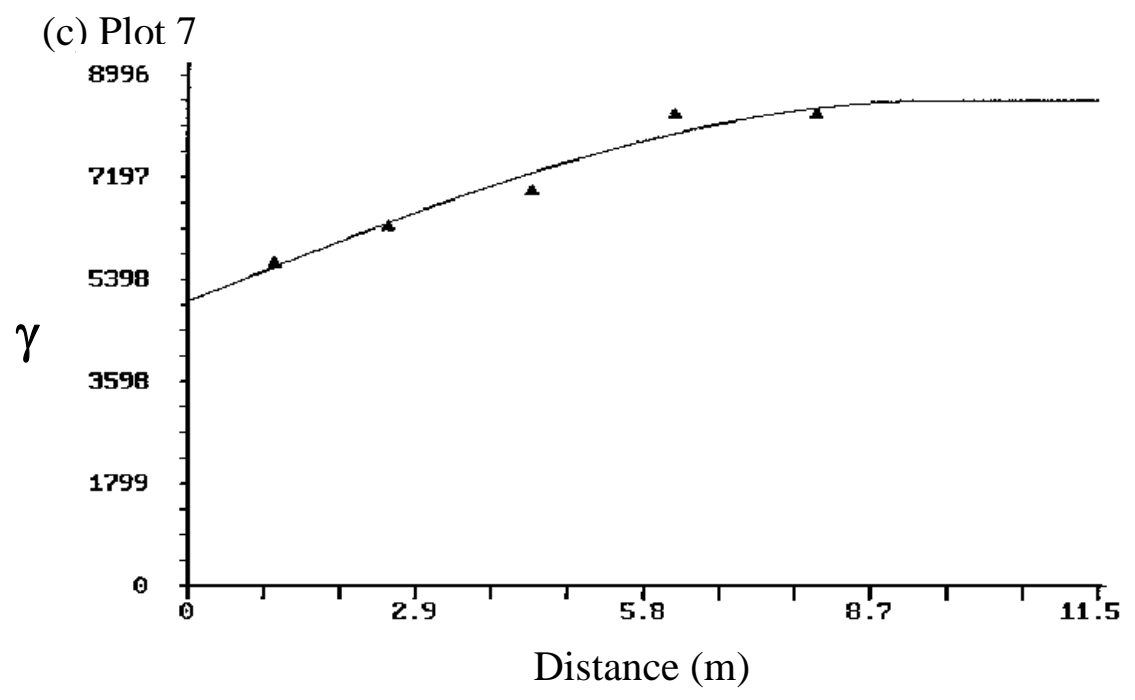

Fig. 7 
PLOT 1
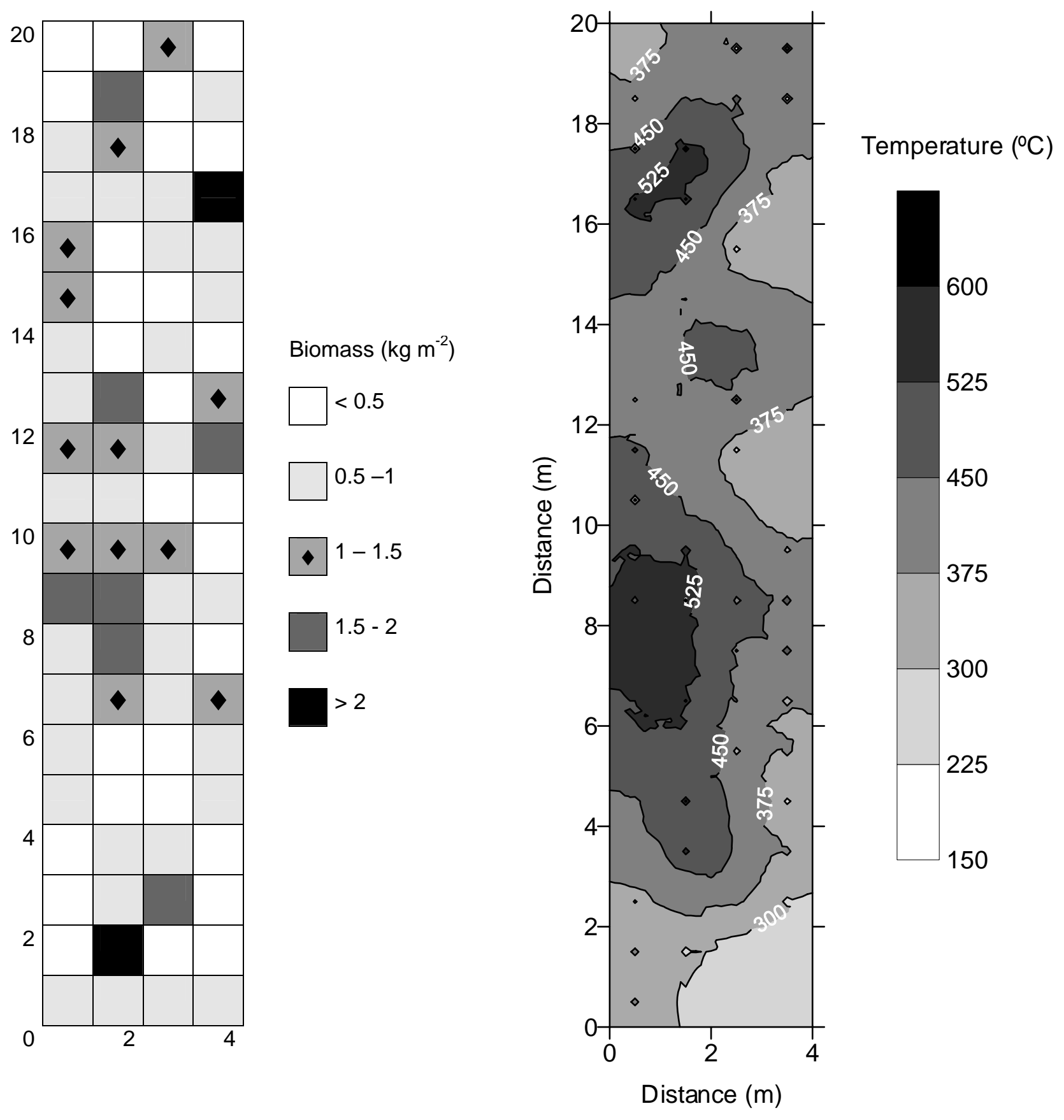

861

Fig. 8

867 
PLOT 4
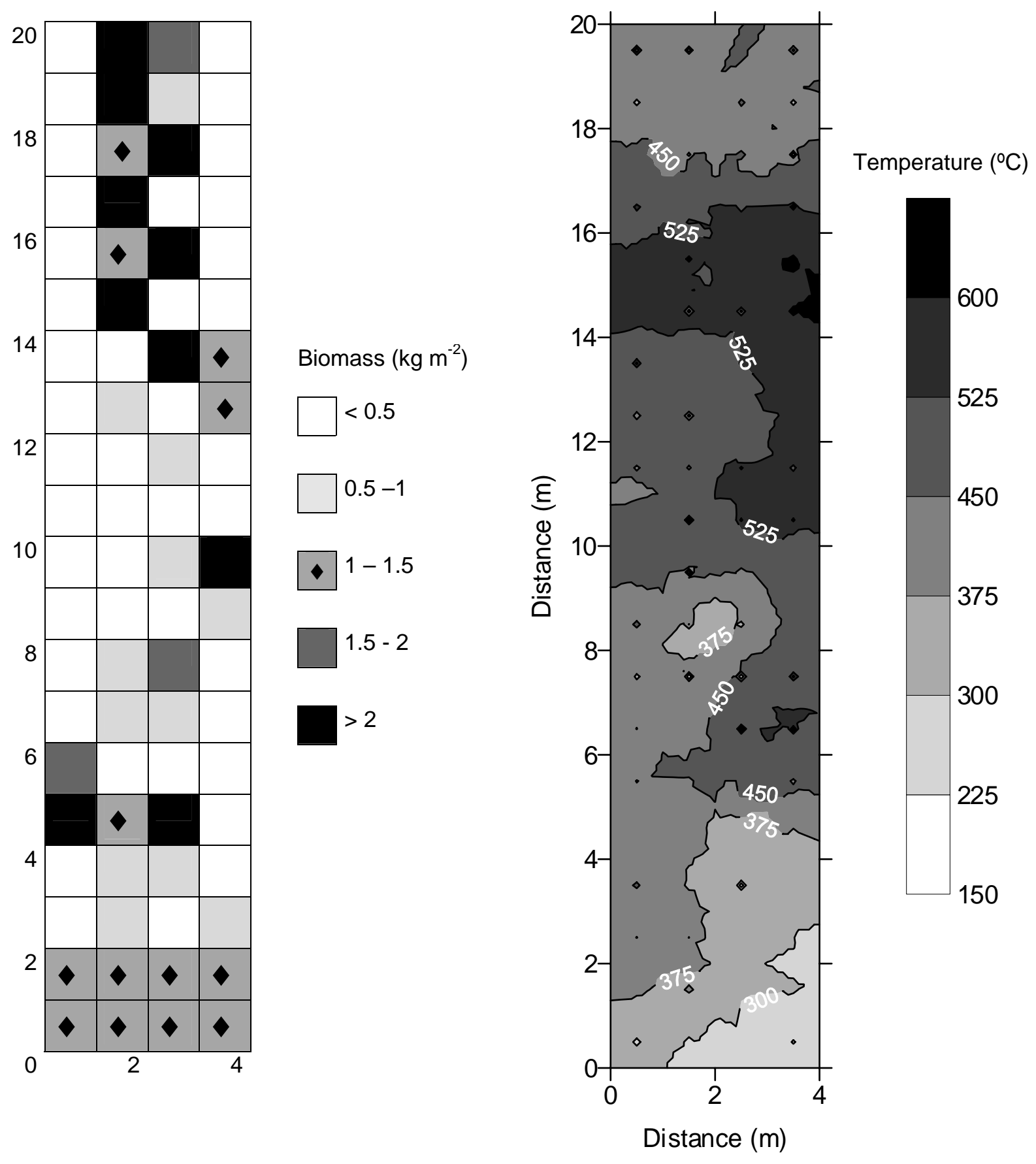

Fig. 9 
PLOT 8
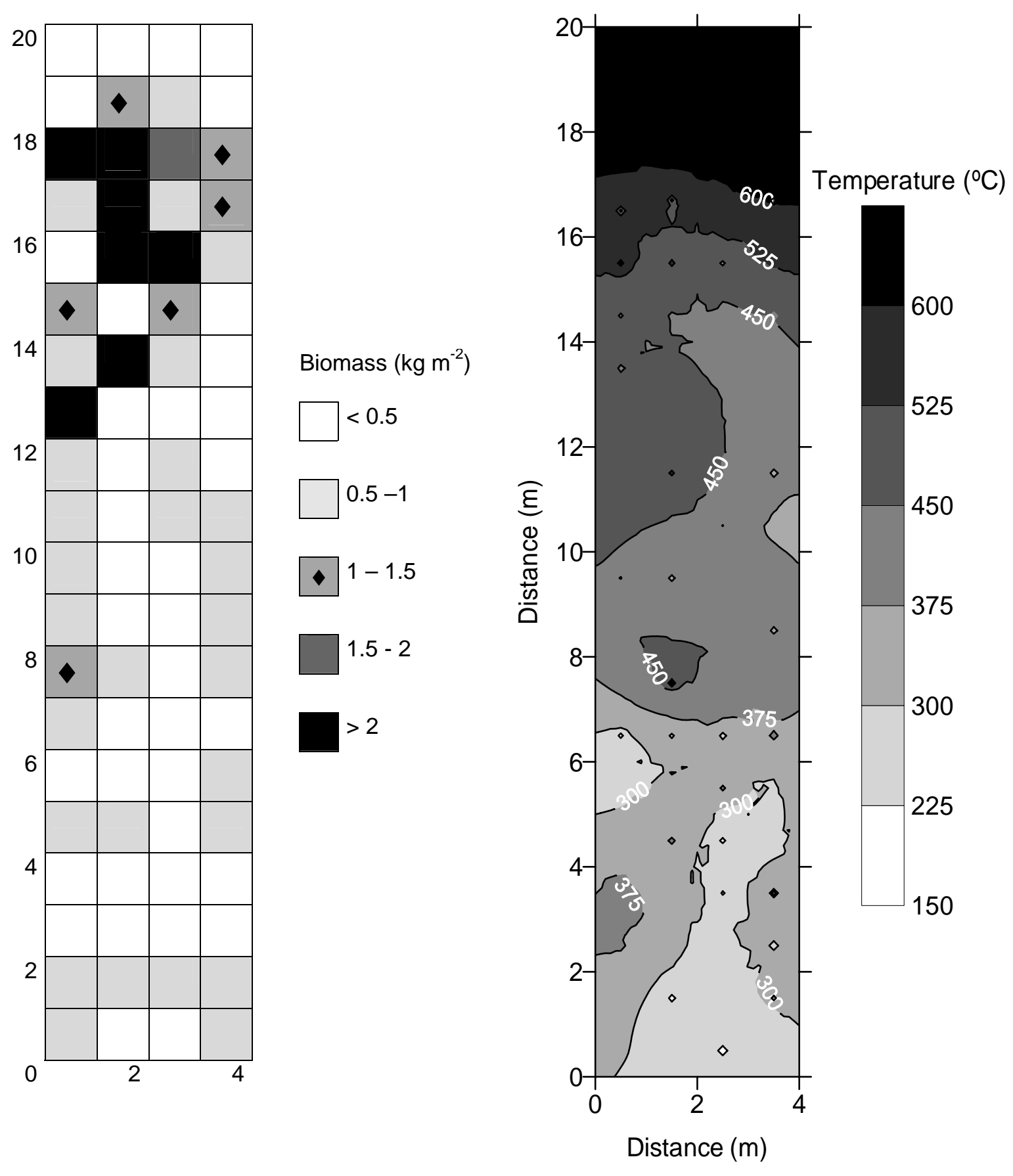

Fig. 10

878 
PLOT 2
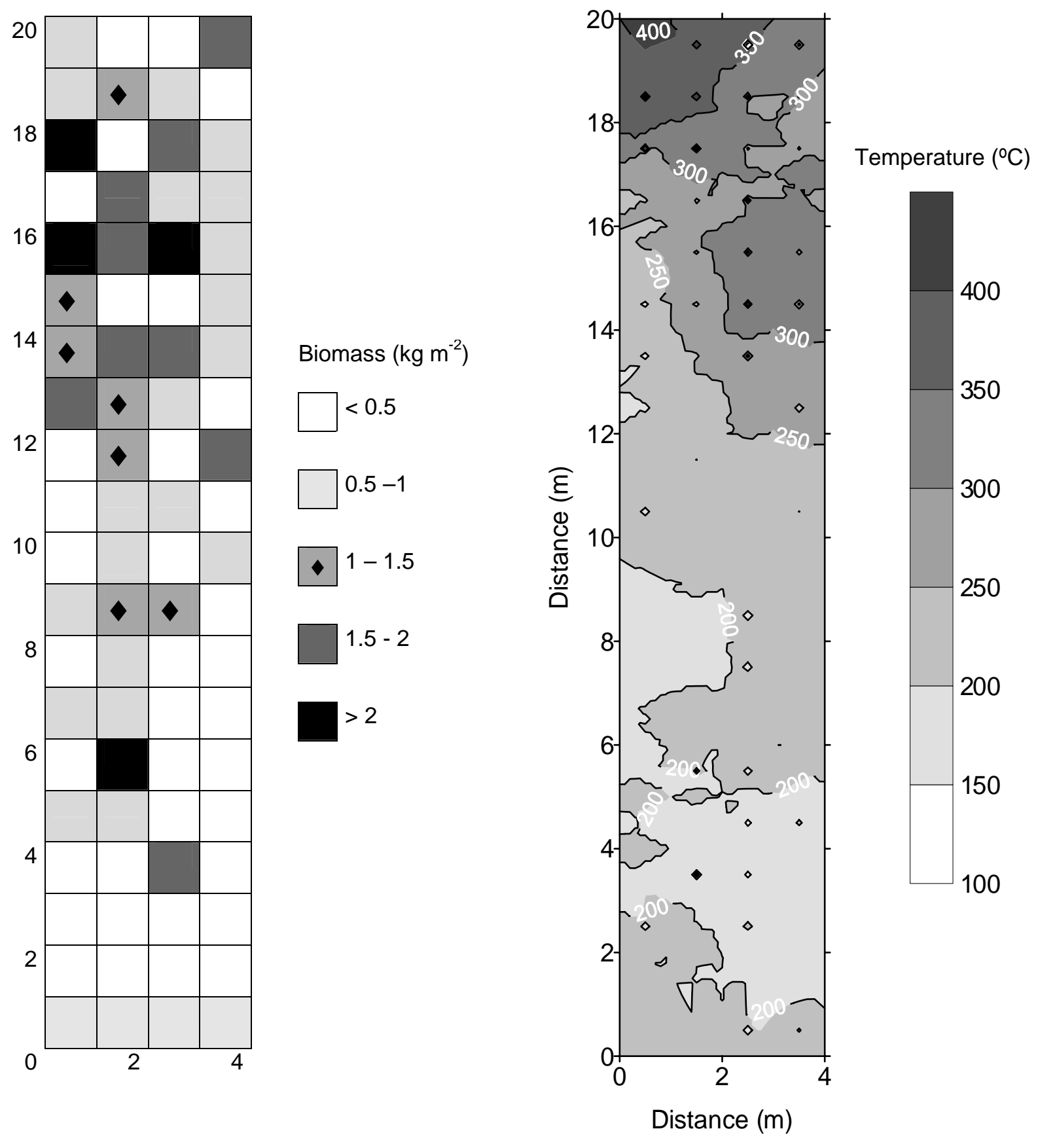

Fig. 11 
PLOT 7
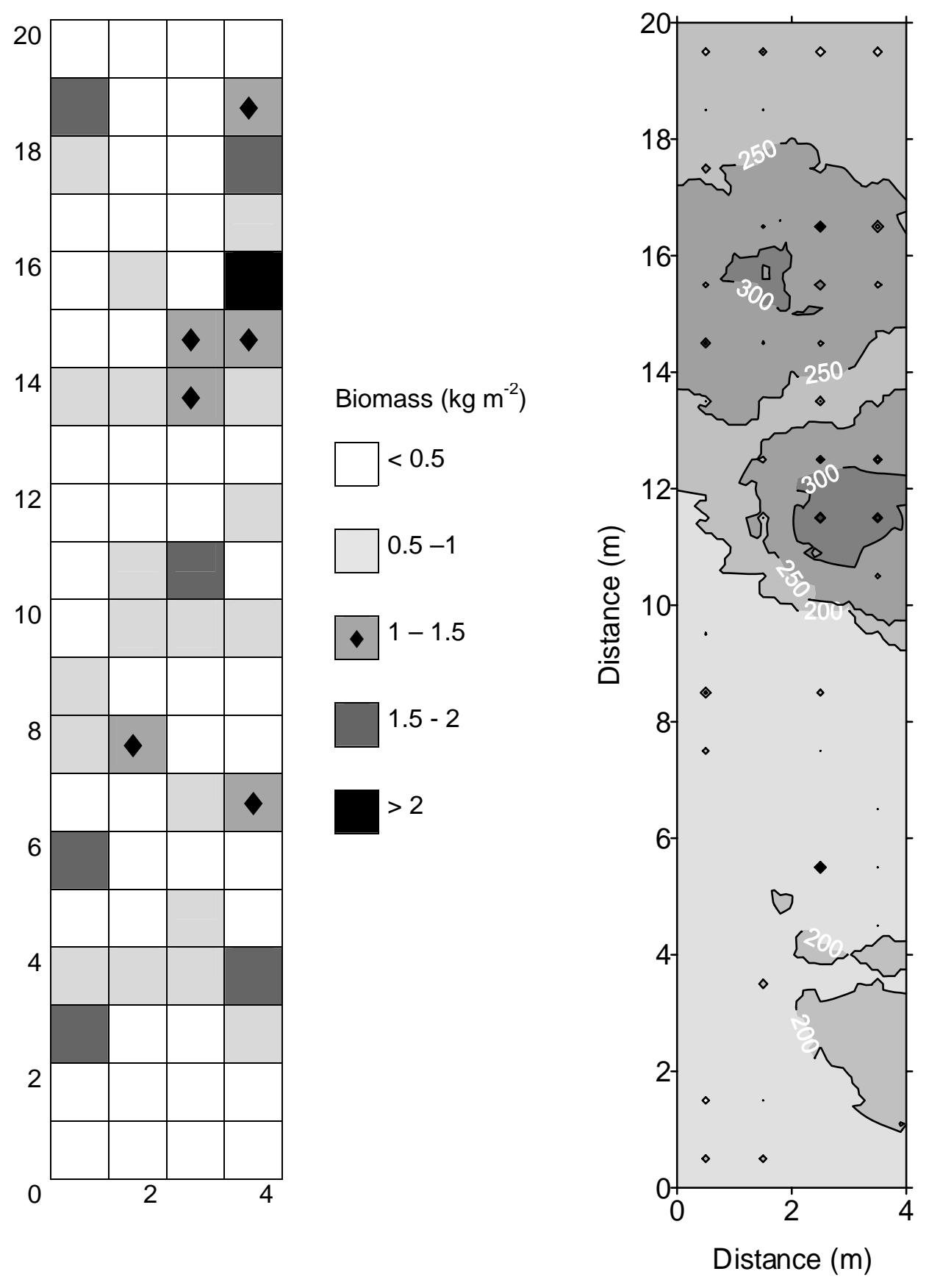

Temperature $\left({ }^{\circ} \mathrm{C}\right)$

Fig. 12 
A)

\section{Cv dry conditions}

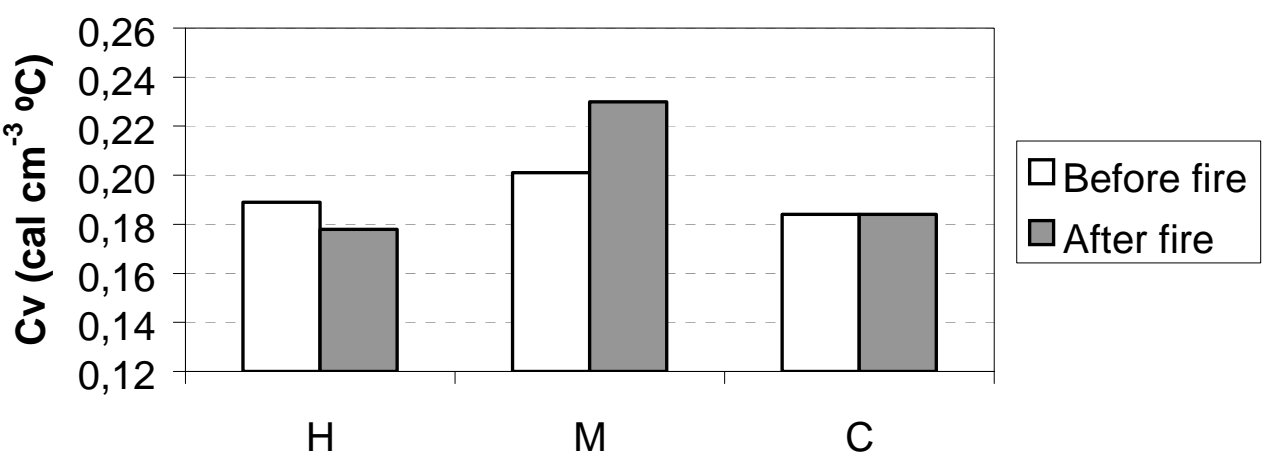

Fire severity

B)

Cv at time of sampling

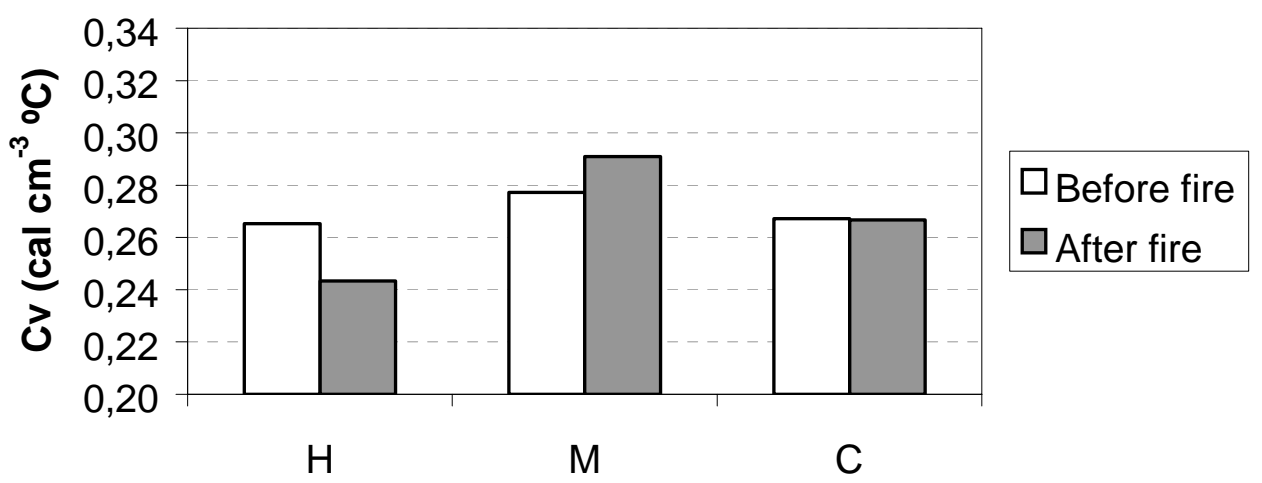

Fire severity

C)

Cv field capacity

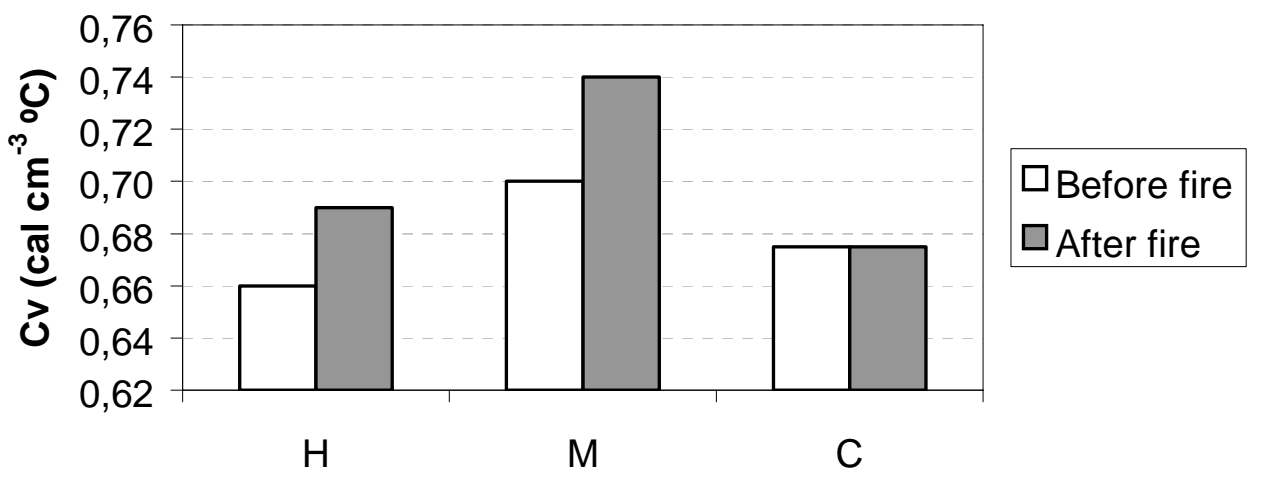

Fire severity 